\title{
PROGNOSTICATION \\ IN CHINESE BUDDHIST HISTORICAL TEXTS \\ THE GĀOSËNG ZHUÀN AND THE XÙ GĀOSENNG ZHUÀN
}

\author{
YANG GANG $^{*}$ AND CHRISTOPH ANDERL ${ }^{* *}$ \\ *Institute for Popular Chinese Culture Studies (中國俗文化研究所) of Sichuan University and \\ Centre for Buddhist Studies at Ghent University \\ No. 29 Wangjiang Road, Wuhou District, Chengdu 610064, P. R. China \\ e-mail: Gang.Yang@ugent.be \\ ${ }^{* *}$ Ghent University, Department of Languages and Cultures \\ Blandijnberg 2, 9000 Ghent, Belgium \\ e-mail: Christoph.Anderl@ugent.be
}

This paper explores topics and techniques of prognostication as recorded in medieval Buddhist historical literature, with an emphasis on the Gāosēng zhuàn 高僧傳 (GSZ) and Xù gāosēng zhuàn 續高僧傳 (XGSZ). The paper first provides a short survey of how prognostication is treated in Chinese Buddhist translated texts. In these 'canonical' sources there is clear ambiguity over the use of supernatural powers: on the one hand, such practices are criticised as non-Buddhist or even heterodox; on the other, narratives on Śākyamuni's former and present lives as well as accounts of other buddhas, bodhisattvas, and the Buddha's disciples abound with descriptions of their special abilities, including knowledge of the future. In contrast, the GSZ and XGSZ display a clear standpoint concerning mantic practices and include them as integral aspects of monastics' lives. The two texts articulate that the ability to predict the future and other supernatural powers are natural by-products of spiritual progress in the Buddhist context. This paper discusses the incorporation of various aspects of the Indian and Chinese traditions in monastics' biographies, and investigates the inclusion of revelations of future events (for example, in dreams) and mantic techniques in these texts. In addition, it traces parallels to developments in non-Buddhist literature and outlines some significant differences between the GSZ and the XGSZ.

Key words: Buddhist mantic practices; prognostication; divination techniques; Buddhist history texts; Gāosēng zhuàn; Xù gāosēng zhuàn.

\section{Introduction}

In recent years, prognostication in China has become a subject of increased Western scholarly interest, resulting in several important publications. ${ }^{1}$ However, whereas

${ }^{1}$ See e.g. the articles collected in Chemla, Harper and Kalinowski 1999 and, more recently, Lackner 2018. For a comparison between ancient Chinese and ancient Greek divination practices, 
previous research has focused primarily on traditional Chinese divination methods, in this paper we will investigate practices described in two of the most important compilations of medieval Buddhist biographies: the Gāosēng zhuàn 高僧傳 ('Records of eminent monks'; hereafter GSZ), ${ }^{2}$ compiled by Huijiăo 慧皎 (497-554) during the Liáng 梁 Dynasty (502-557); and its successor work, the Xù gāosēng zhuàn 續高僧 傳 ('Continued records of eminent monks'; hereafter XGSZ), ${ }^{3}$ compiled by the famous Táng monk and Vinaya specialist Dàoxuān 道宣 (596-667). Together, these two texts contain hagiographies of eminent monks who lived between the end of the Hàn 漢 Dynasty (206 BCE-220 CE) and the beginning of the Táng 唐 Dynasty (618907), and as such they constitute the most important sources of biographical information on Buddhist monastics of the period.

This paper will investigate the various methods of prognostication that are recorded in these works and explore how they were incorporated into the monks' biographical entries. Mantic techniques were of great significance in the cultural repertoires of both ancient India and ancient China, and the compilers ${ }^{4}$ of Buddhist biographies were familiar with both the canonical Buddhist texts (i.e. Buddhist texts translated or compiled based on Indic language material) and the Chinese methods of

see Raphals 2013. For divination texts among the Dūnhuáng manuscripts, see Kalinowski 2003 and Kroll 2018.

${ }^{2}$ T50, no2059. The Taishō edition includes biographies of 257 people, plus a supplement of another 242. The work is divided into fourteen fascicles and ten sections based on a categorisation of monastics. In addition, there is a preface contained in Fascicle 14. The ten categories of monastics are: yì jīng 譯經 ('translators'); yì jiě 義解 ('commentators'); shén yi 神異 ('miracle workers'); xí chán 習禪 ('meditation practitioners'); míng lì 明律 ('Vinaya experts'); wáng shēn 亡身 ('selfimmolators/those engaged in ascetic practices'); sòng jīng 誦經 ('specialists in reading and reciting the scriptures'); xīng fú 興福 ('those generating merit'); jīng shī 經師 ('sütra lecture masters'); and chàng dăo 唱導 ('monks engaged in preaching and conversion'). For a discussion of the GSZ in Western scholarship, see Wright 1954 and Kieschnick 1997.

${ }^{3} \mathrm{~T} 50$, no2060. The sequel to the GSZ, the XGSZ follows the structure of its predecessor in terms of categorisation, although the titles of the categories are sometimes altered. The earliest monks to feature in the XGSZ lived at the beginning of the Liáng 梁 Dynasty, and the latest temporal reference is to the nineteenth year of the zhēnguān 貞觀 era (645) of Emperor Tàizonng of the Táng 唐太宗. Hence, the work covers a period of 144 years. It includes 340 main biographical entries and 160 appended entries. In addition to the edited version in the Taisho collection (30 fascicles), there are 31- and 40-fascicle versions, which contain some variations in both the content and the number of monks recorded. The current Taishō editions are by no means the earliest versions of the GSZ and the XGSZ. The textual history of the latter text is especially complicated. Whereas the extant preface mentions 340 biographies and 160 appended entries, the Korean Kōryo version (高 麗藏) features 414 main and 201 appended biographies. The text seems to have remained relatively stable after the Sòng, with a total of 485 main and 219 appended biographies. For convenience, we will focus exclusively on the Taishō version in this paper. For details of the various editions, see Atsushi 1990 (tr. in Shì Zhàohuì 1992: 202-203, 218) and Chén 2005: 22-29; on case studies, see also Chen 2016, Shinohara 1994 and Yang 2004.

${ }^{4}$ We use the term 'compilers' rather than 'authors' as the GSZ and the XGSZ are primarily collections of existing biographical/hagiographical material written by numerous authors and deriving from a variety of sources, including stele inscriptions and tales of the marvellous (see Kieschnick 1997: 50). This is clearly stated in the GSZ and the XGSZ themselves (GSZ, p418c18-21; XGSZ, p425b16-20). 
divination. As will be shown below, the compilers of the GSZ and XGSZ drew on both of these traditions when integrating references to divination within their works.

\section{Prognostications in Texts Translated from Indic Languages: A Short Overview}

\subsection{Agents and Topics of Prognostication}

\subsubsection{Predictions in Accounts of the Buddha's Life}

One famous Buddhist prediction that appears in a variety of sources relates to events that took place immediately after the Buddha's birth. For example, according to the Fó běnxíng jīng 佛本行經, ${ }^{5}$ King Śuddhodana, Sākyamuni’s father, asked a Brahmin (in some scriptures identified as Asita-r̦̣i) to inspect his son's physiognomy in order to determine his future. The priest recognised all thirty-two marks of a superior man, so he predicted one of two paths for the infant: he would either become a great cakravartin (i.e. a powerful 'wheel-turning king') or he would renounce worldly life and become an enlightened sage. Another example of prognostication in canonical Buddhist literature is a passage in the Fó běnxíng jíjīng 佛本行集經 (T3, no190) in which Māya's dream of a six-tusked white elephant entering her womb is interpreted as foretelling the birth of a saintly person.

Occasionally, in the literature, Śākyamuni himself announces an important future event, such as his impending death and subsequent attainment of nirvāna in the Móhēmóyé jīng 摩訶摩耶經 (*Mahāmāya sūtra): 'Excellent, Pāpīyas! [You] should know that after three months I shall enter nirvāna' (善哉, 波旬 ! 當知如來却後三 月入於涅槃; CBETA: T12, no383, p1011a4-5).

Of course, such references to divination/prediction in the Chinese Buddhist canonical literature stand in stark contrast to Vinaya injunctions against the practice. ${ }^{7}$

\subsubsection{Predictions of Future Attainments and the Spread of the Dharma}

Predictions play an important role in a variety of Buddhist texts. For instance, the jātaka literature contains many references to 'future events', most notably predictions of future buddhahood (shòji 授記, see below) and the fates of close disciples of Sākyamuni. As the frame narratives of the jătakas are often the Buddha's sermons (i.e. the 'relative present'), these predictions tend to be projected into the past and

${ }^{5}$ Sūtra on the Past Activities of the Buddha (T4, no193; translated by Băoyún 寶雲 in the middle of the 5th century). This text is one of the richest sources on the Buddha's life, and two chapters include references to prophecies: Chapter 5 provides an account of a Brahmin physiognomising the Buddha as a baby, and Chapter 6 deals with the prophecies of the ascetic and mantic specialist Asita, Āyí 阿夷.

${ }^{6}$ The translation of this text is traditionally attributed to Tánjīng 昙景 (479-502), but it may have been compiled in China (see Utsuo 1954).

${ }^{7}$ On this issue, see Strickmann 2005: 78-81. 
appear in accounts of the Buddha's practices during previous lives (i.e. the 'relative past'). As such, many of them are verified during the sermon, for instance, by identifying the protagonists in the narrative with the disciples who are currently listening to the Buddha.

With respect to the spread of Śākyamuni's teaching, the Dàoxíng bōrě jīng 道行般若經 (Aștasāhasrikā-prajñāpāramitā sūtra; T8, no224) states:

After the passing away of the Tathāgata, this prajñāpāramitā ("perfection of wisdom') will exist in southern India; after having been studied there, it will be transmitted from southern India to western India; after having been studied there, it will be transmitted from western India to northern India.

怛薩阿竭去後, 是般若波羅蜜當在南天竺, 其有學已, 從南天竺 當轉至西天竺，其有學已，當從西天竺轉至到北天笂。

(CBETA: T8, no224, p446a29-b3)

Similarly, the arrival of the bodhisattva Nāgārjuna is predicted in the Lainkāvatāra sūtra:

After the Tathāgata has been extinct, there will be a person in the future. Mahāmati, listen carefully, a person will maintain my teaching. In a great southern country, ${ }^{8}$ there is a monk of great virtue by the name of Nāgārjuna Bodhisattva, and he will be able to destroy the [false] views about existence and non-existence.

如來滅度後, 未來當有人。大慧汝諦聽, 有人持我法, 於南大國 中, 有大德比丘, 名龍樹菩薩, 能破有無見。

( CBETA: T16, no671, p569a22-26)

\subsubsection{Techniques and Agents of Prognostication in Texts of Indic Origin}

A survey of translations of Indic sources reveals that predictions played an important role in Buddhist narratives. Several techniques can be distinguished, including prophecies based on physical features (i.e. physiognomising, such as the interpretation of the thirty-two marks of a great man), people's names (xiàng ming 相名), ${ }^{9}$ the interpretation of dreams (zhàn mèng 占夢)—most notably Māya's dream of a white elephantand the study of stars and planets. In the following example, taken from the Mishāsāibù héxì wǔfēnlü 彌沙塞部和䤈五分律, ${ }^{10}$ the diviner is a Brahmin who interprets astral constellations:

${ }^{8}$ Nán dàguó 南大國 is synonymous with Nán Zhūguó 南竺國 (Skr. dakșināa patha), i.e. southern India (see Hirakawa 1997: 220).

${ }^{9}$ For example, the Shisong lü 十誦律 (Daśa-bhānavāra-vinaya), a Vinaya text of the Sarvâstivāda School, has the following passage: '[As for] the Brahmins' method of interpreting fetures, if a name is auspicious, then there will be good fortune (lit. “delight”)' (婆羅門相法, 名吉則喜; CBETA, T23, no1435, p99c14).

${ }^{10} \mathrm{~T} 22$, no1421; Skr. Mahīsāasaka-vinaya. 
At that time there was a [Brahmin] fortune-teller who told King Bimbisāra: 'Soon there will (dāng 當) be an inauspicious star appearing; Your Majesty should bathe in the water of a certain spring in order to be spared from ${ }^{11}$ disaster. If Your Majesty does not do so, then this will result in either the loss of your country or mourning over Your Majesty's life [i.e. the king's death].'

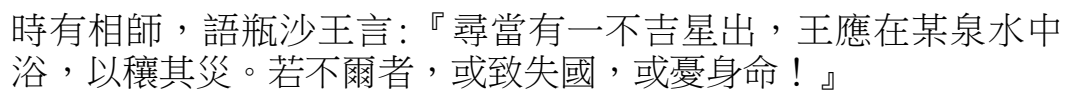

Generally, in the accounts in translated sources, the prophecies/prognostications are provided either by a buddha (usually when predicting the future buddhahood of others) or by a member of the highest caste (i.e. a Brahmin). In the Zhŏng dé jīng 種德 經 (contained within the Cháng ăhán jing 長阿含經), during a conversation with Sákyamuni, a Brahmin suggests that one of the caste's key characteristics is an ability to foretell the future:

As for the five attributes achieved by our Brahmins, what we say is of utmost honesty, without any falseness. What are those five [attributes]? Firstly, our parents of the seven preceding generations were all 'genuine' [zhênzhèng 真正; i.e. members of the Brahmin caste], and were not slandered by other people; secondly, we can recite and are well versed in the Vedic teachings ${ }^{12}$ in three parts, and we can fully discern [i.e. explain in detail] the classical scriptures, and we have deep insight in the subtleties of worldly [i.e. non-Vedic] classics; furthermore, we excel in the method of prognosticating the features a great person, and clearly investigate auspicious and inauspicious features, sacrifices, and rituals; thirdly, our facial attributes are handsome [symmetrical]; fourthly, our observation of the prohibitions is fully sufficient [i.e. perfected]; fifthly, our wisdom is penetrating. These are the five [attributes].

\footnotetext{
${ }^{11}$ The use of ráng 穰 is interesting here. The original meaning is 'stalks of grain' and, by extension, 'abundant; prosperous'. As such, the word refers to something 'auspicious'. Here, it seems to indicate that the 'disaster' ( $z \bar{a} i$ 災) is neutralised (by something auspicious). However, we suspect that 穰 should be read as răng 攘, referring to apotropaic methods of averting disaster by utilising the influence of heavenly bodies. See e.g. the Táng Dynasty Qīyào răngzāi jué 七曜攘 災決 (Secrets of seven-planet apotropaism), a Buddhist astrological manual comprising Chinese, Indian, Iranian, Sogdian, and Near Eastern elements that was used to interpret the effects of the nakșatra (mingsù 命宿; i.e. the stellar constellation at the time of one's birth). See Jeffrey Kotyk and Iain Sinclair's detailed analysis of this text in DDB: http://www.buddhism-dict.net/cgi-bin/ xpr-ddb.pl?q=\%E4\%B8\%83\%E6\%9B $\% 9 \mathrm{C} \% \mathrm{E} 6 \% 94 \% 98 \% \mathrm{E} 7 \% 81 \% \mathrm{BD} \% \mathrm{E} 6 \% \mathrm{~B} 1 \% \mathrm{BA}$. The Qìyào răngzāi jué also prescribes certain actions that should be performed to counter inauspicious effects.

${ }^{12}$ In Buddhist texts, yixué 異學 often refers to unspecified 'non-Buddhist teachings'. However, here it specifically refers to the Brahmins' Vedic scriptures. The expression sānbù jiùdiăn 三部舊典is used in a parallel passage in the Cháng āhán jīng (CBETA: T1, no1, p82a) in reference to the 'ancient classics in three parts' (i.e. the corpus of Vedic scriptures).
} 


\section{我婆羅門成就五法, 所言至誠, 無有虛妄。云何為五? 一者婆羅 門七世已來父母真正，不為他人之所輕毀；二者異學三部諷誦通 利，種種經書盡能分別，世典幽微靡不綜練，又能善於大人相 法、明察吉凶、祭祀儀禮；三者顏貌端正；四者持戒具足；五者 智慧通達。是為五。}

(Cháng āhán jīng, CBETA: T1, no1, p95c28-96a7; emphasis added)

Buddhist texts occasionally juxtapose Brahmin prognostications with those of the Buddha, with the former's erroneous predictions invariably trumped by the latter's correct prophecies. ${ }^{13}$ Moreover, there are accounts of unethical Brahmins using predictions in order to swindle the gullible. ${ }^{14}$

In addition to the Buddha's ability to foretell buddhahood and other accomplishments, some of his disciples are similarly credited with a capacity to predict the future. For instance, they might employ the 'divine eye' (tiānyăn 天眼) they have attained due to their spiritual progress to determine the whereabouts or fate of certain people:

With the power of their divine eyes they surveyed the sentient beings, their passing away here and being [re]born there, their being born here from there, the span of their lives, whether their facial appearance is beautiful or ugly, the receiving of retribution based on their deeds, good and bad rebirth destinations, they have knowledge of all this.

\section{以天眼力, 觀於眾生。死此生彼, 從彼生此, 壽命長短, 顏色好 醜, 隨行受報, 善惡之趣, 皆悉知見。}

(CBETA: T1, no1, p44a27-29)

The Mahāyāna scriptures abound with references to the supernatural deeds of buddhas, bodhisattvas, and disciples of the Buddha. In addition to descriptions of the special powers they have developed through their insight, there are many accounts of their use of 'skilful means' (upāya) — i.e. magic — to promote Buddhism or save sentient beings.

\subsubsection{Some Notes on Terminology}

Despite the critical evaluation of prognostication practices in many Buddhist texts (see below), Chinese translated Buddhist literature includes numerous references to predicting the future as well as interpreting bodily features (xiàng 相), natural phenomena, and so on. One important term is shouji 授記 (lit. 'to bestow a record'; i.e. a 'guarantee' of future enlightenment and attainment of buddhahood; rendering Skr. vyākaraṇa), ${ }^{15}$ which often appears in translated Buddhist literature-including àgama

${ }^{13}$ See e.g. the Guówáng bù li xiān ní shí mèng jīng 國王不黎先泥十夢經, as quoted in the Făyuàn zhūlín's 法苑珠林 chapter on dreams (T53, no2122, p535a-c).

${ }_{15}^{14}$ For an example from the jātakas, see the discussion in Ohnuma 2017: 73.

${ }^{15}$ There are also several phonetic renderings into Chinese of this term. These guarantees of future attainment are so important that they constitute one of the sections in the traditional twelvefold division of the Buddhist canon (shí-èr bù jīng 十二部經). 
literature ${ }^{16}$ - usually in reference to predictions of future buddhahood or some other prospective accomplishment. Another term, xuánji 懸記, ${ }^{17}$ is more difficult to define. It is sometimes used specifically in reference to the Buddha's predictions of future events, but it tends to appear only in Buddhist texts composed in China-as opposed to translated literature - and also has the more general meaning of 'to prophesy'. Several other terms that appear in the canonical scriptures are explained below.

\subsection{Criticism of Prognostication Techniques in the Buddhist Canon}

The Buddhist canonical texts are highly critical of Brahmin prognostication and divination practices. ${ }^{18}$ In Buddhist philosophy, the emphasis is on phenomena arising due to primary and secondary causes. Moreover, crucially, the future is dependent on one's actions in the present. So, the assumption of a determined course of events projected into the future is by default problematic. ${ }^{19}$ This may be one of the reasons why 'traditional' prognostication techniques are routinely condemned and associated with non-Buddhists (i.e. Brahmins). For example, the following passage from the Fó kāijiě fànzhì Ābá jīng 佛開解梵志阿䫻經 (Sūtra on Buddha's enlightening of the Brahmin Ambatțha), ${ }^{20}$ contained in the agamas, denounces various prognostication practices:

[Śrāmaneras] should not study physiognomising [xiàng 相; i.e. prognostication based on bodily/physical features] concerning [the birth of] sons or daughters, becoming poor or rich, esteemed or humble; or whether

${ }^{16}$ For example, the Zēngyī āhán jīng 增一阿含經 contains an account of the past Buddha Dìngguāng informing the Brahmin Chāoshù 超術 that he will be reborn as Śākyamuni Buddha. (On this Brahmin, see CBETA, T2, no125, p597c18ff.) Similarly, the Janeśa-sütra (Shénishā jīng 闍尼 沙經), which forms part of the Dìrghāgama (Cháng āhán jīng), includes a passage in which the Buddha predicts that Chancellor Qiéqiéluó 伽伽羅 (Skr. *Gagara?) and twelve others will ascend to a heavenly realm after their deaths. Elsewhere in the same text, he announces that fifty people will attain the stage of sakrd-āgāmin (sìtuóhán 斯陀含; 'once-returner') after their deaths, while another five hundred will attain the level of srotâpanna (xūtuóhuán 須陀洹; 'stream-enterer'). Such examples are commonplace.

${ }^{17}$ There are various ways to interpret the semantics of xuán (lit. 'suspend') in this term. It can mean 'far away', and as such may refer to an event in the distant future; alternatively, it may mean 'publicly announce' (i.e. proclaim future buddhahood).

${ }^{18}$ For a thorough study of key passages in the Buddhist canon (with an emphasis on the Vinaya literature), see Guggenmos 2018.

${ }^{19}$ However, as Kotyk 2018 has recently noted, astrological determinism is an integral part of Buddhism. Buddhists in India, with few exceptions, believed that time was conditioned by astrological circumstances, and that future developments could be forecast through astrology, in contrast to the assumption that Buddhists ought to believe in a chain of causality based on the theory of karma.

${ }^{20}$ This text (parallel to the Pāli Ambattha sutta of the Dīgha Nikāya) was supposedly translated by Zhī Qiān 支謙 in the first half of the 3rd century and is thought to reflect early Buddhist thought. However, this attribution is far from certain. For instance, Nattier 2008 does not include the text among the earliest Chinese Buddhist translations. 
there are features or no features. Furthermore, [śrämaneras should not] interpret the behaviour of the six domestic animals. ${ }^{21}$ [Śrammaneras should not] engage in divination (kăozhàn 考占) concerning extraordinary events such as flooding, droughts, or natural disasters, as well as years of plenty or hardship. Śrammaneras should not observe above (yăngguān 仰觀) the celestial cycles and numbers [i.e. astrological signs $],{ }^{22}$ and should not calculate the phases of (tuībù 推步) waxing and waning, and the eclipses of the sun and moon, falling stars, irregular appearances, the collapse of mountains, earthquakes, and the [prevalence of] wind and rain during the seasons; all of that should not be known [i.e. prognosticated].

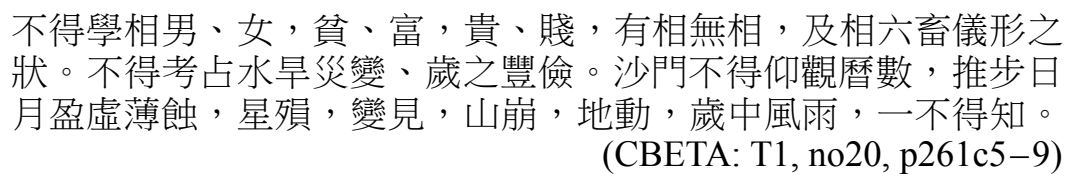

Likewise, the Vinaya in Four Divisions (*Dharmaguptaka-vinaya; Sifên lü 四分律) displays a very critical attitude towards all prognostications and predictions, defining them as practices of 'non-believers' (wàidào 外道) and people who do not live

${ }^{21}$ Liùchù 六畜 is a traditional Chinese term for domestic animals (sometimes specifically for horses, cows, goats, pigs, dogs, and chickens). It is often contrasted to the 'six kinds of beasts' or the 'six kinds of birds' (cf. Zhōuli 周禮：庖人掌共六畜、六獸、六禽, 辨其名物; Shisān jīng zhùshiu: 661). Because of the significance of domestic animals, it was important to predict their 'futures' on the basis of their physical characteristics. The Hànshū 漢書 (Chapter Yì wén zhì 藝文 志, p1775) mentions a text with the title Xiàng liùchù 相六畜 (Physiognomising the Six Domestic Animals) in thirty-eight fascicles (see Raphals 2008-2009: 91, Note 157). There seems to be no corresponding term in an Indic language, and the translator Zhīqiān 支謙 used an expression with which his Chinese readership would be familiar. Although the term itself is drawn from the Chinese cultural sphere, the technique of prognosticating the futures of animals is also attested in translated literature. For example, the Gēnbèn shuō yìqiè yǒubù pínàiyé 根本說一切有部毘奈耶 (Mūla-sarvâstivāda-vinaya-vibhanga) mentions several types of prognostication in a narrative on the abilities of a young boy: 'As for the eight kinds of techniques, he excelled in physiognomising the following: treasures, garments, residences, cows, elephants, horses, men and women' (於八種術善能占相： 所謂相寶、相衣、相宅、相牛、相象、相馬、相男、相女; CBETA: T23, no1442, p629a9-10; emphasis added). However, there is no concrete description of these techniques, and we do not know if they were similar to those practised in China.

${ }^{22}$ Thus, śrammaneras should not engage in practices that are associated with Brahmins. The fact that astrology was related to the Brahmins may also be deduced from the titles of the following (no longer extant) works listed in the Suishū 隋書 (Chapter Jingjí zhi 經籍志, pp. 1019 and 1026): Póluómén tiānwén jīng 婆羅門天文經 (Scripture on the astral practices of the Brahmins), in 21 fascicles; Póluómén Jiéqié xiānrén tiānwén shuō 婆羅門竭伽仙人天文説 (Astral teachings of Brahmin Sage *Garga; on this text, see Kawai and Kōzen 1995), in 30 fascicles; Póluómén suànfă 婆羅門算法 (The method of [calendar] calculations of the Brahmins), in 3 fascicles; Póluómén yīnyáng suànli 婆羅門陰陽算曆 (The scripture of Yinnyáng and [calendar] calculations of the Brahmins), in 1 fascicle; and Póluómén suànjīng 婆羅門算經 (The scripture of [calendar] calculations of the Brahmins), in 3 fascicles. However, Kotyk 2017a: 66-67 points out that these references in the Suish $\bar{u}$ do not necessarily reflect the routine association of astrological practices with Brahmins; rather, 婆羅門 should be interpreted as a more general reference to 'India'. 
correctly. The following passage lists a number of mantic techniques that run counter to following the Buddhist path:

Non-Buddhist śrammanera, brahmins eat the alms of those of other faiths [e.g. Buddhist believers], [and] obstruct the methods of the [correct] path [i.e. the Buddha-dharma], and they do not earn their livelihood properly, they examine the good and bad features of the appearance of men and women in order to predict their future. ${ }^{23}$ They prognosticate on the features of various domestic animals in order to seek profit; [Buddhist believers] eradicate these various [Brahmin] methods of obstructing the [correct] path.

如餘沙門、婆羅門, 食他信施, 行妨道法, 邪命自活, 瞻相男女 好惡, 相種種畜生, 以求利養, 斷除如是種種妨道法。

$$
\text { (CBETA: T22, no1428, p963b10-13) }
$$

Some chant the books on differentiating between death and life; some chant the books on classifying the dreams, some determine the features of the hands [i.e. read palms] or the shoulders, some recite the questions to Heaven and men, ${ }^{24}$ some chant the books on differentiating between the sounds of birds and beasts. [Buddhist believers] eradicate these various [Brahmin] methods of obstructing the [correct] path. ${ }^{25}$

或誦別死生書 ; 或誦別夢書 ; 或相手相肩 ; 或誦天人問 ; 或誦別 鳥獸音聲書, 除斷如是妨道法。

(CBETA: T22, no1428, p963b19-27)

When they prognosticate on the features of Heaven, some say it will rain, some say it will not. Some say that the grain will be expensive, some say it will be cheap. Some claim there will be many sicknesses, some say there will be few. Some say there will be dreadfulness, some say there will be peace. Some state that the earth will shake, some say comets will appear. Some say there will be an eclipse of the moon, some state there will not be. Some say there will be an eclipse of the sun, some state there will not be. Some claim there will be an eclipse of a star, some say there will not be. Some state that the eclipse of the moon is

${ }^{23}$ Zhàn xiàng 瞻相 is usually written as 占相. The term zhàn xiàng, which occurs frequently in Buddhist texts, refers to prognostication based on the features of people, things, or natural phenomena. It is often encountered in narratives relating to the newborn Sākyamuni, whose marks of a great man are inspected and interpreted. On the practice of physiognomy, see Despeux 2003.

${ }^{24}$ Based on the passage in another text, this is probably a reference to 'books on astrology' (tiānwén shū 天文書, mentioned in the Cháng āhán jīng; CBETA: T1, no1, p84c3). Thus, our text is likely corrupted here.

${ }^{25}$ A similar passage from the Ambatta Sutta (T1, no1, p84b15-c13) is translated as: 'Oder sie rezitieren Bücher zur Unterscheidung von Leben und Sterben, sie lesen Bücher über Träume, sie lesen aus der Hand. Sie lesen Bücher über Astrologie oder über alle Laute' (Meisig 1987: 253). See also Guggenmos 2018: 194. 
a such-and-such good response, some say it is a such-and-such bad response. As for [the interpretations of] the eclipses of the sun and the stars, they are also as such. [Buddhist believers] eradicate these various [Brahmin] methods of obstructing the [correct] path.

瞻相天時, 或言當雨, 或言不雨; 或言穀貴, 或言穀賤; 或言多 病, 或言少病; 或言恐怖, 或言安隱; 或言地動, 或言彗星現; 或言月蝕, 或言不蝕; 或言日蝕, 或言不蝕; 或言星蝕, 或言不 蝕; 或言月蝕有如是好報有如是惡報, 日蝕星蝕亦如是, 除斷如 是邪命法。

(CBETA: T22, no1428, p963b27-c6)

Meanwhile, in the Prajñāpāramitā literature, prognostication practices are criticised because they do not conform to the doctrine of the emptiness of all intrinsic features (zìxiàng 自相). For example, the Mahāprajñāpāramitā sūtra (Dà bōrě bōluómìuō jing 大般若波羅蜜多經; T5, no220) defines an advanced bodhisattva as someone who 'knows that all intrinsic features of all phenomena are empty, and within the emptiness of all self-features one cannot discern any features' (知一切法自相皆 空, 自相空中不見有相; CBETA: T6, no220, p674b25-26). Therefore, it is futile to try to 'interpret the features' (xiàng 相) of things, and one should not

physiognomise whether life will be long or short, whether there will be riches and [high] positions, [whether a child will be] male or female, [or try to predict] all kinds of good and evil matters; one should also not foretell (xuánji 懸記) coldness or heat, bounty or poverty, good or bad auspicious signs, good and evil, [and by so doing] confuse the sentient beings.

\section{占相壽量長短、財位、男女諸善惡事，亦不懸記寒熱、豐儉、吉 凶、好惡, 惑亂有情。}

(CBETA: T6, no220, p674b21-23)

In addition, the Mahāparinirvāna sūtra (Dà bānniépán jīng 大般涅槃經) states that engaging in various kinds of prognostication might engender societal criticism. Therefore, 'a bodhisattva mahāsattva should put an end to the world's criticism of the prohibitions’ (菩薩摩訶薩息世譏嫌戒; CBETA: T12, no374, p433a20) and monastics should avoid all mantic practices. This text also provides a detailed list of (heterodox) prognostication techniques (終不瞻相手、足、面目，不以爪鏡、芝草、 楊枝、鉢盂、髑髅而作卜筮; CBETA: T12, no374, p433a14-15). Several of these techniques are mentioned in a passage on the forty-eight minor prohibitions in the Fànwăng jīng 梵網經:

[As for the methods of using] the 'fingernail-mirror', milfoil grass, branches of the willow, bowls, and skulls for prognosticating, one should not employ any of them; [...] if one employs them, then one commits a minor offence. 


\section{爪鏡、著草、楊枝、鉢监、髑髏而作卜筮，一一不得作 $(\cdots \cdots)$ 若 故作者, 犯輕垢罪。 \\ (CBETA: T24, no1484, p1007b18-20) ${ }^{26}$}

The zhuă jìng 爪鏡 ('fingernail-mirror') method is described in a Táng Dynasty commentary on the Mahāparinirvāna sütra as 'smearing medicine [i.e. ointment] on the [palm of the] hands [to produce a reflective surface] and cast a spell on it; then one is able to see whether [a matter] will be auspicious or inauspicious' (爪鏡者, 以藥塗 爪呪之，能見吉凶; Nièpán jīng shū sī ji 涅槃經疏私記; CBETA: X37, no661, $\mathrm{p} 214 \mathrm{c} 4)$. The method is also mentioned in the Tiāntái púsà jièsh $\bar{u}$ 天台菩薩戒疏, where it is stated that it was used by 'magicians from the Western countries' (西國 術師; CBETA: T40, no1812, p595c16). As such, it is not considered a traditional Chinese technique. $^{27}$

Divination by milfoil grass (Achillea millefolium; in other sources zhīcăo 芝草, Zoysia pungens) seemed to involve casting a spell or incantation on the plant, then providing a prediction on the basis of that.

Indian monastics used branches of the willow (yáng 楊) to cleanse the mouth and the body. In a commentary on the Brahmajāla sūtra, the Fànwăng púsà jiè jīng yish $\bar{u} f \bar{a}$ y̆n 梵網菩薩戒經義疏發隱 (CBETA: X38, no679), this practice is explained as follows: a priest casts a spell over a willow or camphor branch and thereby invokes the plant's spirit. Another commentary, the Fànwăng púsà jiè zhù 梵網菩薩戒注 (CBETA: X38, no691), provides a more detailed explanation: a figure in the shape of a person is carved from a piece of willow or camphor, a spell is cast on the branch, and this summons a spirit who has the power to predict a person's or an undertaking's future prospects. Yet another account appears in a work by the Qing Dynasty scholar Yuán Dòng 袁棟, the Shū y̌̀n cóng shūo 書隱叢説 (Xù xīu sikù quánshū, Vol. 1137 , p. 574): a miniature model of a person is carved from the wood of one of the aforementioned trees and a spell is cast that causes a gifted and intelligent child to die. The child's soul is then captured within the carved piece of wood and urged to make prognostications. ${ }^{28}$

${ }^{26}$ For a comprehensive discussion of the various mantic practices and their classification in the Buddhist canon, as well as possible parallels in Pāli literature, see Guggenmos 2018. For a discussion on Vinaya monks and astral practices, see Kotyk 2017b.

${ }^{27}$ The technique is also referenced in the Bĭqiüní zhuàn 比丘尼傳 (T50, no2063, p935a725), specifically in the biography of the nun Ān Lìngshǒu 安令首: 'Chong [the nun's father] consulted Buddhatunga about the matter. Buddhatunga said to him, "Go back home and keep a pure fast for three days, and then come again". Chong obeyed him. Buddhatunga mixed some red paste with sesame oil, rubbed it into the palm of Chong's right hand, and asked him to look at it. He saw a Buddhist monk with features resembling his daughter's preaching the Dharma to a great assembly. He described this to Buddhatunga, who said, "That was your daughter's previous incarnation: she was a monk working for the benefit of others. Such was her former life. If you comply with her wish, she will bring glory and exaltation to all the six relations of your family and make you rich and noble; and she may reach the other shore across the great sea of the suffering of rebirth"' (Li and Dalia 2006: 74).

${ }^{28}$ There are also occasional references to the use of willow branches in divination in works of Esoteric Buddhism (cf. Tuóluóní jí jīng 陀羅尼集經; CBETA: T18, no901, p888a8-12). 
The use of alms bowls (bōyú 鉢盎) in divination is also considered a 'Western' practice. It involved casting a spell that enabled the diviner to foretell the future simply by looking into their bowl. The Fànwăng púsà jiè jīng shūzhù states:

[As for the] the alms bowl, non-Buddhists of the Western countries apply a spell (zhò 呪) to all kinds of utensils, letting people prognosticate auspicious and inauspicious [events] in them; here, the alms bowl is mentioned and this is such a utensil. In this region [i.e. China] one can also apply a spell to a cup/bowl (wăn 碗) in order to prognosticate; all [vessels] are like this [i.e. potentially have this function].

鉢盎，西土外道呪一切器物令人於中卜吉凶，此以鉢盎為言，即 器也。此方亦有呪水椀以卜者, 皆此類。

(CBETA: X38, no678, p118b22-24)

Finally, the Buddhist scriptures mention two methods of extracting information from skulls. The first technique - which was associated with India-involved tapping the skull and making predictions based on the sound. ${ }^{29}$ By contrast, the second method was rooted in traditional Chinese practices: 'One takes the skull of a recently deceased person and ceremoniously casts a spell on it; then one is able to listen to the skull and report disasters and fortunate events' (取新亡髑髏祭鍊禁呪, 能從人耳報 災祥也; Fànwăng púsà jiè jīng yìshū fā y̆̀n 梵網菩薩戒經義疏發隱; CBETA: X38, no679, p202a9-10). It seems that the soul or spirit of the deceased person played some sort of role here. ${ }^{30}$

Based on this short survey of prognostication in Chinese Buddhist translated literature, we may conclude that many divination techniques and topics (such as predicting an ordinary person's fate or a ruler's future prospects) were regarded as heterodox and attributed to non-Buddhists (especially Brahmins), whereas prognostication performed by Buddhists usually focused on religious subjects, especially a person's prospective enlightenment and buddhahood. In general, mantic practices that were unrelated to Buddhist topics were criticised and often defined as heterodox.

\section{Predictions in the GSZ and XGSZ}

We will now investigate the presentation of topics and methods of prognostication in two highly influential historical works - the GSZ and XGSZ - which had a significant impact on how the ideal qualities of eminent monks were defined in the Chinese context. In contrast to the translated Buddhist literature discussed above, these texts display an unambiguous attitude towards mantic practices, leaving the reader in no doubt that mastery of prognostication and other supernatural powers are essential characteristics of eminent monks. These powers are rarely mediated by a spirit or

${ }^{29}$ Cf. Móhē zhĭguān 摩訶止觀 (CBETA: T46, no1911, p101a1-2).

${ }^{30}$ For an early example of a skull 'becoming alive' and representing the spirit of the deceased person, see Zhuāngž̆ 莊子 18 (Guō and Wáng 1961: 617-619). 
a divination/mantic specialist; rather, they are directly communicated by the monastic himself. (Occasionally, information about a future event is revealed first in a dream, ${ }^{31}$ either explicitly or encoded in a 'riddle'.) Hence, the monk gains knowledge of future events and attains supernatural powers (shéntōng 神通) through arduous Buddhist practice. The process that leads to the attainment of these special powers sometimes forms part of the narrative, so the reader is told both why and how a particular monastic gained his supernatural prowess. For instance, the entry on Sēnghuì 僧慧 (408-486/487) reads as follows:

At that time there was furthermore Huìyuăn 慧遠 from the Chángshā Monastery of Jiānglíng. He was the attendant of the monk Huìyin 慧印 there. When [Hui]]yìn saw that he [i.e. Huìyuăn] had faith, he urged him to renounce [his] home. [Huìyuăn] then made an effort in the practice of pratyutpanna, ${ }^{32}$ and after years of austerity, he then acquired supernatural powers, ${ }^{33}$ and was able to duplicate his body when he accepted invitations [i.e. he could be at two locations at the same time], and he predicted periods of flourishing or decline, among other things.

時江陵長沙寺, 又有釋慧遠者。本沙門慧印之蒼頭也。印見其有 信, 因為出家。仍行般舟之業, 數歲勤苦, 遂有神異, 能分身赴 請，及預記興亡等。

(GSZ, p393c17-20; emphasis added)

Another example is the biography of Buddhabhadra, ${ }^{34}$ who reportedly travelled by ship to China. At the start of his voyage, he correctly predicted a change in the direction of the wind, an encounter with pirates, and other ominous events. This foreknowledge is attributed to the fact that he was a 'non-returner' (Skr. ānägamin), so he had been endowed (jùzú 具足) with the gift of premonition. ${ }^{35}$

Taking this into account, how does one explain the special powers of monks who were not especially virtuous or even broke the precepts? One such monk was Băozhì 保誌 (418-514) who 'did not settle at any specific place, ate at improper times, and had hair several inches long’ (居止無定, 飲食無時, 髮長數寸; GSZ,

${ }^{31}$ Of course, prognostication based on dreams is a cross-cultural phenomenon (see Stevens 1997). This also plays an important role in the GSZ and XGSZ. Even more significantly, in these sources, future events are often explicitly revealed in dreams and so do not necessarily need reinterpretation. For a detailed discussion of monastic dream interpretation in the GSZ and XGSZ (with a specific focus on hermeneutics), see Jensen 2018: 119-123.

32 This probably refers to the practice of reaching pánzhōu sānmèi 般舟三昧, a contemplation in which one visualises being together with the present Buddha (pánzhōu means 'present').

${ }^{33}$ Shényi 神異 (lit. 'divine anomaly').

${ }^{34}$ Fótuóbátuóluó 佛䭾跋陀羅 (358/359-429), a famous translator as well as a Vinaya and meditation master.

${ }^{35}$ See, e.g. the Chánmì yàofă jīng 禪祕要法經: “When one successively cultivates and attains the four fruits of a śrammanera, "three insights" and the "six supernatural powers" will all be provided' (次第修得四沙門果, 三明、六通皆悉具足; CBETA: T15, no613, p244a29). 
p394a18). As such, he fell far short of the monastic ideal. ${ }^{36}$ Nevertheless, he was able to predict the future. The GSZ attempts to resolve this apparent paradox by stating that he gained this ability through vigorous practice in previous lives. So, despite his unorthodox behaviour during his current lifetime, he displayed great confidence at the time of his death, announcing: 'I, the bodhisattva, am about to leave' (菩薩將去; GSZ, p394c22)! He is also said to 'have exposed his true form [to his disciples], with a glow like the one of bodhisattva statues' (為其現真形, 光相如菩薩像焉; GSZ, p394c19). Hence, he revealed his true nature to his followers based on his previous achievements.

Although this 'self-power' based on strict adherence to Buddhist practice is the most important factor in the acquisition of prognostication (and other supernatural gifts), the GSZ and XGSZ sometimes credit other agents, such as ghosts, mediums, and deities, with similar abilities. In addition, predictions are often accompanied by other unusual and supernatural occurrences. ${ }^{37}$

\subsection{Topics of Predictions}

\subsubsection{Predictions relating to the Lives of Eminent Monks}

Important events in monks' lives are the most prominent topic of prognostication in the GSZ and XGSZ. These texts contain numerous predictions relating to individual monks' gestation, birth, death, and rebirth, in addition to narratives concerning key achievements in their lives, spiritual attainment, and enlightenment.

\subsubsection{Gestation and Birth}

The narratives concerning the conception and birth of Śakyamuni are elaborately described in the Buddhist literature in order to show that he was a superior being from the very beginning. They include his mother's dream of a white elephant, his entry into the womb, his birth from his mother's side, and other stories. Likewise, the Chinese Buddhist biographies of eminent monks abound with descriptions of unusual events that either preceded or coincided with their birth.

A mother's dream often foretells an auspicious birth. ${ }^{38}$ For instance, in Xuángāo's 玄高 (402-444) entry, his mother dreams of 'Indian monks (fànsēng 梵僧) who scatter flowers, filling the room' (梵僧散華滿室; GSZ, p397a8), while the mother of Huiyue 慧約 (452-535) dreams of a 'tall person lifting up a golden image and causing her to swallow it' (長人擎金像令吞之; XGSZ, p468b23-24). The mother of Huìŏng 慧勇 sees 'herself climbing up a Buddha-stūpa, getting hold of

\footnotetext{
${ }^{36}$ On 'deviant' monastics, see the discussion of 'meat-eating, wine-drinking monks' in Kieschnick 1997: 51-63.

${ }^{37}$ On the Chinese worldview that 'supernatural' occurrences form part of the natural world, see the discussions in Campany 1996: 205-272 and Sharf 2002: 77-133.

${ }^{38}$ For a detailed discussion of the logic and poetics of conception dreams in the GSZ and the XGSZ, see Jensen 2018: 149-219.
} 
two golden bodhisattvas' (身登佛塔, 獲二金菩薩; XGSZ, p478a24), while Zhìyăn's 智琰 mother 'ascends the pagoda of Tōngxuán monastery, ${ }^{39}$ climbs up the sign of the wheel, ${ }^{40}$ and takes a seat there' (夢升通玄寺塔, 登相輪而坐; XGSZ, p531c4-5). Finally, Língruì's 靈睿 mother dreams of an 'alms bowl made of the seven treasures dropping down from a tree and flying into her mouth' (七寶鉢於樹顛飛來入口; XGSZ, p539c15). Such accounts, replete with Buddhist symbols, occur frequently in Buddhist historical texts.

Specific elements of Chinese culture are also sometimes woven into the dreams, such as in the dream of the mother of Tándì 曇諦 (347-411). She meets a monk who 'entrusted her with a fly-whisk and two iron-engraved paperweights' (寄一塵尾并鐵鏤書鎮二枚; GSZ, p370c26-27). A fly-whisk is also mentioned in Zhìwén's 智文 mother's dream: 'An Indian monk took a branch from a pine tree and gave it to her, saying, "If you thereafter give birth to a boy, bestow a fly-whisk on him” (梵僧把松枝而授, 曰：『尔後誕男, 與為塵尾』; XGSZ, p609b8-9). The zhǔwěi 塵尾 ('fly-whisk') featured prominently in qīngtán 清談 ('pure talk') debates at the imperial court during the Six Dynasties period. ${ }^{41}$

Zhìzàng's 智藏 (458-522) mother dreamed that 'meteors fell on the ground, she grabbed and swallowed the debris; because of this, she fell pregnant and gave birth to [Zhì]zàng; at a young age, he was already very bright' (眾星墜地取而 吞之, 因而有娠焉, 及生藏也, 少而聰敏; GSZ, p465c11-12). Meanwhile, the mother of Cízàng 慈藏 (?-?) dreamed of 'a star falling down and entering her, and because of that she became pregnant' (星墜入懷，因即有娠; XGSZ, p639a16). ${ }^{42}$

Other signs - such as changes in the mother's mental or physical dispositioncould also predict the birth of an eminent monk. For example, during her pregnancy with the famous translator Kumārajīva (344-413), his mother reportedly had 'extraordinary realisations ${ }^{43}$ (自覺神悟超解, 有倍常日; GSZ, p330a19). Similarly, when

${ }^{39}$ This monastery (now Bàoēn-sì 報恩寺) is situated in present-day Sūzhōu City, Jiāngsū Province. Its history can be traced back to the Three Kingdoms period, when it was established by Emperor Sūnquán 孫權 of the Kingdom of Wú 吳 in honour of his wet nurse (see Jiājing Wúyì zhì 嘉靖吳邑志 16, in Tiānyī gé cáng Míng-dài fāngzhì xuănkān xùbiān: 1153).

${ }^{40}$ This refers to a sign in the form of a wheel or a circle that was placed on top of a pagoda. A wheel sign on the feet of a cakravartin was also one of the marks of a great man. See Jensen 2018: 197-201.

${ }^{41}$ When answering a question, a debater would raise his fly-whisk. When unable to answer, or to admit defeat, he would lower his whisk (see Assandri 2009: 25). Before long, the implement also started to feature in Buddhist rituals. By the end of the Táng, it signified the power of Chán masters, who would brandish fly-whisks when addressing the assembly or teaching students. On the sexual imagery of Zhìwén's mother's dream and its thematic relationship with other conception dreams in the GSZ and the XGSZ, see Jensen 2018: 197-201.

${ }^{42}$ Secular Chinese historical texts also address the topic of astral bodies causing pregnancy. For instance, see Shiji i 史記, fasc. 49 (p1975), which records that the mother of Emperor Wŭ of Hàn (漢武帝) dreamed that the sun entered her and thereafter she gave birth to her son. For the significance of this astral imagery in the GSZ and the XGSZ, see Jensen 2018: 186-193. For additional examples from roughly the same historical period, see Lippiello 2001. For a later discussion of this oneiric imagery in Chinese historical texts, see Strassberg 2008: 108-114.

${ }^{43}$ The motif of psychological change in the mind of the mother probably originated in an account of the birth of Sākyamuni's famous disciple Sáriputra. The Dà zhìdù lùn 大智度論 (Mahā- 
Făláng 法朗 (507-581) dwelled in his mother's womb, her 'four limbs felt “light and unreal", different from regular days, and because of that she abstained from the various flavours of the five pungent roots' (四體輕虛，有異恒日，五辛雜味，因此悉 斷; XGSZ, p477b5-6). The theme of abstaining from the five pungent roots (wǔxin 五辛 $)^{44}$ during pregnancy is also found in the biographies of Huibì 慧壁, Língruì, Huìjìn 慧璡 (401-485), and Kōngzàng 空藏.

Supernatural phenomena during and after birth often indicate the arrival of an extraordinary person. For instance, 'clouds and vapours filled the room' (見雲氣滿 室; XGSZ, p463c14-15) at the moment of Făyún’s 法雲 (467-529) birth. Similarly, the entry on Zhituō 智脱 $(541-607)$ relates: 'In the beginning, on the evening of his birth, a divine light radiated through the room, and during a period of ten days, a driedup spring gushed forth by itself' (初誕之夕, 神光照室, 旬日之間, 枯泉自涌; XGSZ, p498c3-4). The XGSZ offers an explanation of such phenomena in the following story:

His mother, Ms. Zhāng, on the first day of her pregnancy, ascended the pagoda of the Tōngxuán Monastery in a dream, and in the distance she saw emptiness approaching (yuăn shì lín $x \bar{u}$ 遠視臨虛). However, she never showed any expression of fear. The superior omens (shèng zhào 勝兆) of attaining the way and transcending life are the supreme mysterious features of a teacher of men.

母氏張夫人，初懷孕日，夢升通玄寺塔，登相輪而坐。遠視臨 虛，曾無懼色。斯乃得道超生之勝兆，人師無上之奇徵。

(Zhìăn 智琰 entry, XGSZ, p531c6; emphasis added)

Hence, there was no need for a mantic specialist to interpret these auspicious phenomena, ${ }^{45}$ because they were, by default, indications of the advent of a saintly person (even prior to his enlightenment) in the world.

prajñāpāramitā-śāstra, attributed to Nāgārjuna) states: 'Because of this child, the mother was also [highly] intelligent and had great skills in debates. When the younger brother Jūchíluó 拘郄羅 engaged in dispute with his elder sister [i.e. the mother of Sanriputra], each time he was outwitted and proven inferior to her. Thus, he knew that the child she was bearing certainly had great wisdom' 以其子故, 母亦聰明, 大能論議。其弟拘郗羅, 與姊談論, 每屈不如, 知所懷子, 必大智慧 (CBETA: T25, no1509, p137c11-13).

${ }^{44}$ There are various lists of these items, but the term usually refers to roots of the onion family (e.g. leeks, scallions, garlic, chives, etc.). These roots were thought to arouse the minds of practitioners, causing passion and distracting them from their spiritual quest. See, e.g. the Fànwăng jīng 梵網經, which lists dàsuàn 大赫, gécōng 革葱, cícōng 慈葱, láncōng 蘭苾, and xīngqú 興莧 (CBETA: T24, no1484, p1005b14-16); or the Púsà jièyì shü 菩薩戒義疏, which lists suàn 赫, cōng 憼, xīngqú 興葉, jiǔ 菲, and xiè 薤 (CBETA: T40, no1811, p575a25-26).

${ }^{45}$ See Jensen 2018: 119-123 on the distinction between dream interpretation and dream exhortation in the GSZ and the XGSZ. See also the discussion on early medieval Chinese omens and omenology in Lippiello 2001: 25-79.

Acta Orient. Hung. 73, 2020 


\subsubsection{Supernatural Phenomena relating to Death}

In Buddhist hagiographical sources, eminent monks are frequently portrayed as being in complete control of the time and circumstances of their death. They are rarely caught by surprise and often announce their passing well ahead of time. This is well illustrated in the GSZ's biography of Dàoli 道立 (?-?):

Later, he followed [Dào]ān and entered the Pass, and lived concealed on Mt. Fùzhōu, ${ }^{46}$ dwelling in solitude on a mountain peak of Mt. Fùzhōu, not receiving any offerings. Whenever he was immersed in contemplation and entered meditation, he would not arise for an entire period of seven days; and he had already practised that for several years. Later, in the beginning of summer, he suddenly left the mountain and gathered (jiüji 鳩集) an assembly of monks to lecture them personally on the Great Chapter [i.e. Mahāprajñāpāramitā sütra]. When someone enquired about the reason for this, he answered: 'It is possible for me to stay until autumn arrives, and I wish to eliminate the unrefined [i.e. impurities] that I [still] harbour.' Several days after he had performed a repentance ritual (zizi 自恣), ${ }^{47}$ he finally passed away without sickness. The people of his time referred to him as somebody who knew his fate [destiny].

後隨安入關, 隱覆舟山, 嚴居獨處, 不受供養。每潛思入禪, 輯
七日不起, 如此者數矣。後夏初忽出山, 鳩集眾僧, 自為講大
品。或問其故, 答云: 『我止可至秋, 為欲令所懷粗訖耳。』自
恣後數日, 果無疾而終。時人謂知命者矣。

(GSZ, p356b20-24; emphasis added)

According to this passage, Dàolì had foreknowledge of his impending death (as is indicated by the term zhi ming 知命 in this context) and therefore left the mountain to address unfinished business.

In addition to eminent monks' prior knowledge of the exact moment of their passing, there are countless references to supernatural phenomena at the time of death. This theme appears frequently in the GSZ and XGSZ, with death signalled by unusual odours (yi xiāng 異香) filling the room, unusual sounds, bright lights or colour changes, strange behaviour among animals, earthquakes, strong winds, the sudden disintegration of an item (e.g. a monk's bowl, a carriage axle, a tree branch, a flagpole, etc.), meteor showers, dry rivers and ponds, and so on. Furthermore, the impending death is often foretold in dreams in which Indian monks, Buddhist assemblies, Buddhist statues, or heavenly creatures or deities either welcome the dying monk

${ }^{46}$ Several mountains in China share the name Fùzhōu-shān 覆舟山. However, in this instance, this may be an error. The mountain in question is more likely to be Fùchē-shān 覆車山, which is situated approximately $30 l \grave{l}$ southeast of Lántián in modern-day X̄̄̄ān City (see Lèi biān Cháng'ān zhì: 166).

${ }^{47}$ Repentance rituals were usually performed after the end of the summer retreat. 
or lead him to a Pure Land. Several of these phenomena frequently occur simultaneously to indicate the monk's passing.

\subsubsection{Knowledge of One's Place of Future Rebirth}

In the GSZ and XGSZ, there are often correlations between the appearance of auspicious signs prior to death and the destination of rebirth. For example, the biography of Huitōng 慧通 states:

He was constantly praying for the Pure Land, and he wished to rest his soul in that land. ${ }^{48}$ When he was slightly ill, he envisioned in his meditation a man approaching; his appearance was very handsome, and he told [Huì]tōng: 'The excellent time ${ }^{49}$ has arrived [i.e. to die and be reborn in a Pure Land].' In an instant he saw [in his contemplation] the $\operatorname{nimbus}^{50}$ of the Buddha of Immeasurable Life [i.e. Amitāyus] radiating. Because of this, [Huì]tōng awoke from his state of dhyāna and gave a full account of what he had seen to his fellow students. After telling them, he transformed [i.e. died].

常祈心安養, 而欲栖神彼國。微疾乃於禪中見一人來, 形甚端 嚴, 語通言：『良時至矣。』須因見無量壽佛光相暉然。通因覺 禪。具告同學所見, 言訖便化。

(GSZ, p398c9-13)

In this story, there is a clear relationship between Huitōng's wish to be reborn in Amitabha's paradise and his vision prior to passing away. Similarly, Zhìtuō's 智脫 (541-607) biography records:

Before passing away, he dreamed of a youth who held a lotus flower in his hand, saying: 'Śakra Devānām-Indra has sent me here to request you to lecture [for him].' On the day when his life was about to end, he saw this sign [apparition] once more.

未亡之前，夢一童子，手執蓮華云：『天帝釋遣來請講。』臨終 之日，又見此相。

(XGSZ, p499b23-24)

Interestingly, there are also instances of monks engaging in vigorous practice and consequently receiving predictions of future rebirth, but ultimately experiencing 'lastminute' changes. For example, Línggàn 靈幹 (535-612) seemingly passed away after suffering a severe illness. However, his disciples were reluctant to bury him, because his heart still felt warm. Indeed, the eminent monk eventually woke up ${ }^{51}$ and informed $91-125$.

${ }^{48}$ Anyăng 安養 and b̌̌ guó 彼國 are alternative terms for the Pure Land of Amitabha.

${ }^{49}$ On liáng shi 良時, see Nakamura 1975: 1447b.

${ }^{50}$ Guāngxiàng 光相 (Skr. avabhāsa) is the light that emanates from the body of a buddha.

${ }^{51}$ On this trope in medieval Chinese hagiography and miracle tales, see Campany 1990: 
his devotees that he had visited Tusita Heaven and encountered the famous Dharma master Huiyuăn 慧遠 (334-416), who had informed him that he was destined to be reborn there, too. However, Línggàn had declined Huìyuăn's 'offer', because his main focus of devotion and study was the Avatamsaka sütra, so he wished to be reborn in the Lotus Treasure World (liánhuá zàng shijiè 蓮華藏世界— the Pure Land that is described in this sütra). Later, he lost consciousness again and saw himself sitting on a wheel-shaped flower that was floating on water. On the basis of this auspicious omen, the original prediction of rebirth in Tusita Heaven was 'corrected' to the Lotus Treasure World (XGSZ, p518b14-c27). ${ }^{52}$

\subsubsection{Achievements in a Monk's Life}

In addition to prophecies relating to the birth or death of eminent monks, the GSZ and XGSZ both contain predictions of monastics' spiritual accomplishments, such as enlightenment, and other personal achievements. For example, the biography of Dàohéng 道恒 (346-417), a disciple of the famous translator Kumārajīva, includes the following forecast:

Dàohéng was a person from Lántián. At the age of nine, he was playing on the road when the hermit Zhāngzhōng saw him and said: 'This young boy has the features of an extraordinary person (chürén 出人) $;^{53}$ if he remains in worldly life, he will certainly have the achievement of assisting the task of the government; if he resorts to the Way, he will certainly have the ability to reveal the Buddha-dharma. I regret that I am already old and will not be able to witness this.'

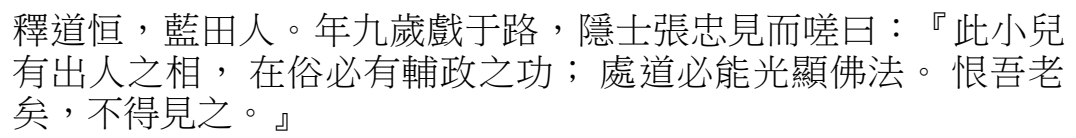

(GSZ, p364b23-26)

This passage clearly alludes to predictions that were made following the birth of Śăkyamuni, ${ }^{54}$ such as whether he would choose to pursue a position of great worldly

${ }^{52}$ In addition to the three cases cited above, the GSZ contains accounts of predictions of rebirth in a Pure Land for Sēngjì 僧濟 (?-?), Zhú Sēngxiăn 笂僧顯 $(222-321 / 322)$, Fǎlín 法琳 (572-640), and Huìjìn. The XGSZ records similar predictions for Shànzhòu 善昌 (550-620), Dàojié 道傑 (573-627), Dào'áng 道昂, Míngshàn 明贍 (565-633), and others. Moreover, there are details of predictions of Xuánzàng's 玄裝 (602-664) rebirth in Tuṣita Heaven, Zhēnyù's 真玉 (??) in the Pure Lotus Buddha Land (jìng liánhuá fóguó 淨蓮華佛國), and Língruì's 靈睿 (565647/648) at the palace of Avalokiteśvara Bodhisattva in the Southern Sea. There are also predictions of rebirth in the realm of the gods (tiāndào 天道) for Huìshào 慧紹 (424-451/452) in the GSZ, and for Băoyì 寶意 (367-431), Băoqióng 寶瓊 (504-584), and Tányăn 曇衍 (503-581) in the XGSZ. Finally, the latter text includes a prediction that the monk Huiléng 慧稜 (?-?) will be reborn at the court of King Yama in the netherworld.

${ }_{53}^{53}$ A person whose capabilities exceed those of ordinary people.

${ }^{54}$ On a similar prediction associated with the childhood of the famous monk Zhìy 1 智顗, see Shinohara 1992: 118. This topic is also addressed in Jensen 2018: 208-215. 
power or become an enlightened saint. It is also significant because it involves a 'nonBuddhist' medium - the hermit Zhāngzhōng (隱士張忠), who was a Daoist practitioner of considerable renown. ${ }^{55}$ Non-Buddhist mediums and physiognomists appear several times in the GSZ and XGSZ, although their prognostications sometimes prove incorrect and have to be revised. It seems that the compilers of the Buddhist historical works used this device to underline the superiority of Buddhist prognostication over non-Buddhist/Daoist fortune-telling. ${ }^{56}$

Băoqióng's 寶璳 (504-584) outstanding monastic career is predicted when he is still a young monk:

In the beginning, when [Băo]qióng entered the capital, he was about to approach the Dharma-seat [i.e. the place where monks gather to practise], but since nobody recognised him, he was not allowed to dwell in the monks' quarters. Thereupon he asked the superintendent Huìchāo if he might lodge at the Nánjiàn Monastery; [Huì]chāo listened to him, but did not allow it. [When] seeing him, [however,] he said in surprise: 'This young talent will carry on my current position, and the Dharmagate [i.e. the teaching] will be entrusted to him. How could I venture ${ }^{57}$ not [to let him stay] in the monks' quarters?'

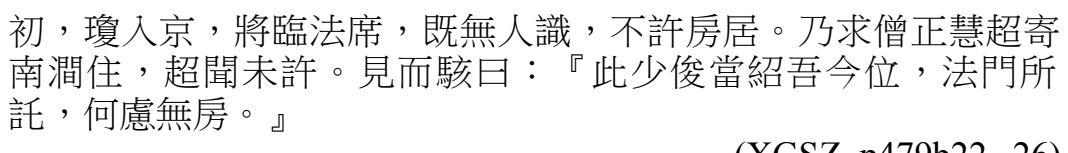

(XGSZ, p479b22-26)

As we have seen, it was assumed that famous monastics had foreknowledge of the time and circumstances of their own death. In addition, the GSZ and XGSZ contain several accounts of monks trying to exert control over their future destination of rebirth. Moreover, predictions relating to those destinations could be modified in order to correlate more closely with a monk's religious achievements and preferences during his lifetime.

\subsubsection{Enlightenment and Spiritual Progress}

The attainment of enlightenment and future buddhahood is the most important topic of prediction in translated Buddhist texts, where it is usually expressed as shoujì (see above). However, as such predictions are typically made by a buddha (in Indic Buddhist literature, usually by either Śākyamuni himself or-especially in the jătaka narratives - a previous buddha), this term scarcely features in either the GSZ or the XGSZ. Indeed, it appears only once, in the entry on the monk Tánróng 曇榮 (555-639):

\footnotetext{
${ }^{55}$ On Zhāngzhōng, see, e.g. Sāndòng qúnxiān lù 三洞群仙錄, fasc. 10 (道士張忠, 永嘉之 初隱于泰山。服氣食芝, 穴地窟爲室, 弟子亦穴居, 其教以形不以言, 朝廷累召, 所賜不受).

${ }_{56}$ More generally on this issue and the widespread belief in spirit mediums in medieval China, see Campany 2012: 40 and Jensen 2018: 334-355.

${ }^{57}$ Iriya and Koga 1991: 16-P29.
} 
[Tán]róng practised in the Făzhù Monastery of the provincial capital the 'method of vast [universal] repentance' (fāngděng huífă 方等悔法) ${ }^{58}$ On the 4th day of the 7th month, there was a certain Sengding of that monastery who was very energetic in the practice of the prohibitions, and he saw a bright light in the place of religious practice [dàochăng 道 場 $;^{59}$ probably, here, a simple reference to the monastery], originating from within a five-coloured [rainbow] with the seven buddhas [of the past] in the middle, [all of them equipped with] extraordinary auspicious signs. [One of the buddhas] addressed Senngding and said the following: 'I am Vipaśyin Tathāgata [i.e. one of the former seven buddhas], not attached to anything, and of perfect universal enlightenment. ${ }^{60}$ Since you already have extinguished your sins, I came here to witness for you, but since I am not your original teacher, I will not make the prediction of buddhahood to you (shouji).' The other six buddhas uttered the same words to him. The last buddha told him the following: 'I am your original teacher Śākyamuni, and since your sins have been extinguished, I came here to make this prediction to you. Tánróng is the good cause that you have extinguishing your sins, and he will be a buddha called Pŭníng 普寧佛 in the "Good Aeon" [i.e. Skr. bhadra-kalpa]; your bodily vessel is [likewise] pure and thereafter you will [also] become a buddha by the name of Pǔmíng 普明.'

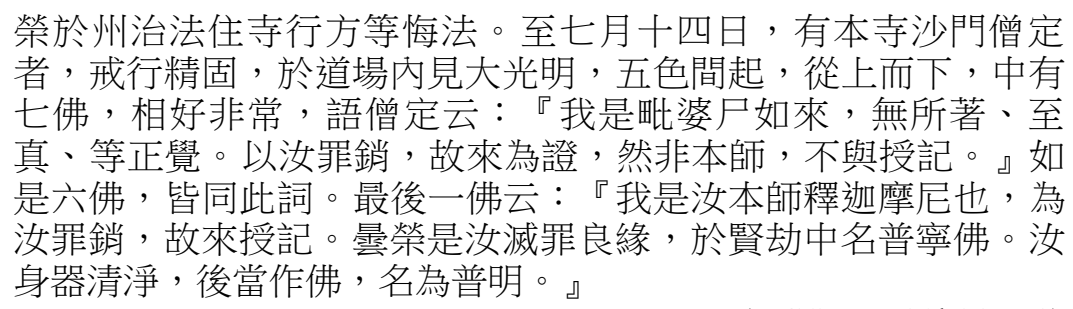

(XGSZ, p589b28-c8)

Here, then, Sēngdìng's devoted Vinaya and repentance practice, under the tutelage of Tánróng, results in a prediction of buddhahood for both monks from Śākyamuni himself. This probably reflects the view of the compiler of the XGSZ, who himself was a renowned Vinaya specialist. However, it is the only occasion when Śākyamuni (or any other buddha) makes such a pronouncement in the text.

${ }^{58} \mathrm{~A}$ more common term for this practice is fängděng chànhul̆ 方等懺悔, which comprises a meditation during which the practitioner focuses on the hindrances caused by the six sense organs.

${ }^{59}$ On the term dàochăng, see DDB (http://www.buddhism-dict.net/cgi-bin/xpr-ddb.pl?q=\% E9\% $81 \% 93 \% \mathrm{E} 5 \% \mathrm{~A} 0 \% \mathrm{~B} 4)$.

${ }^{60}$ Zhizhēn dèng zhèngjué 至真等正覺 usually refers to the enlightenment of an arhat (Skr. arhan sammā sambuddhah) or a buddha. 
There is no specific forecast of buddhahood in Qiúnàbámó's 求那咙摩 ${ }^{61}$ biography, although his entry does include a prediction that he will attain a stage of spiritual development that will enable him to follow the path to buddhahood in the future. In this case, the predictor is not a fellow monk, but rather a prognostication specialist who makes a prediction that is similar to the one given to Sākyamuni after his birth. Interestingly, the passage ends with Qiúnàbāmó's personal evaluation of his spiritual progress:

When he reached the age of eighteen, a prognostication specialist (xiànggōng 相公) saw him and said the following: 'At the age of 30 you will rule a country [i.e. Kashmir] and become an honoured person facing south [i.e. a king/emperor]; [but,] if you do not yearn for worldly fame, you will attain the saintly fruit [i.e. enlightenment]' [...] On the 18th day of the 9th month of that year, he had not yet finished his midday meal when he got up and returned to his room, his disciples following behind. Thereupon, he passed away at the age of 65 . Before his death he had in advance composed a commemorative text in 36 lines, explaining himself his life events (yinnyuán 因緣) and mentioning that he had already attained the 'second fruit' (èrguó 二果). ${ }^{62}$

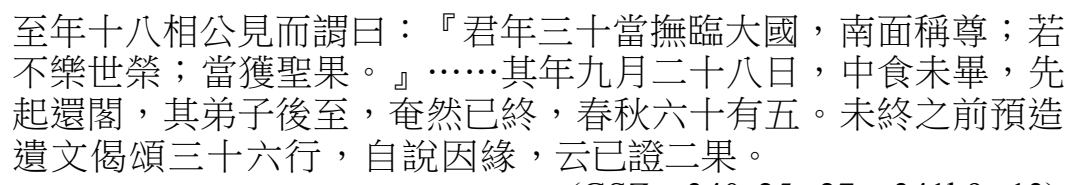

(GSZ, p340a25-27; p341b9-13)

As we have seen, then, the GSZ and XGSZ contain many predictions relating to key events in eminent monastics' lives, including their spiritual accomplishments. Indeed, a monk's progress on the Buddhist path is often clearly defined, and - as exemplified above - may even culminate in a prediction of buddhahood.

\subsubsection{Predictions relating to the Fate and Significance of Buddhism}

\subsubsection{The Flourishing and Decline of Buddhism and the Buddhist Teachings}

From the Northern and Southern Dynasties (and especially Northern Wèi) period onwards, anxiety over the decline or even disappearance of the Dharma (mòf $\tilde{a}$ 末法) became a recurring theme in Buddhist discourse. This is also reflected in the GSZ and XGSZ, in which predictions relating to the future of Buddhism are incorporated within a number of the monks' biographies: in the GSZ, Huì'ān 慧安 (354-424), Tánshǐ 昙始 (?-?), Xuángāo 玄高 (402-444), and Sēngzhōu 僧周 (?-?); and in the

${ }^{61}$ The Kashmiri monk * Gunavarman (367-431) who translated key Vinaya texts during the Líu Sòng 劉宋 period (420-479). He was also a member of the Kashmiri royal family and as such a potential successor to the throne.

${ }^{62}$ That is, he had attained the realisation that would make him a 'once-returner'. 
XGSZ, Huìs̄i 慧思 (515-577/578), Huìzhŭ 慧主 (541-629/630), Dàomì 道密 (564659), Shétísinà 闍提斯那 (?560-?656), Míngdàn 明誕 (?560-?656), and Sēngmíng 僧明 (?-?). The narrative is especially dramatic in the case of Xuángāo, who passes away but is then summoned back from the dead by his disciples and asked to make a prediction on the future of the Dharma. After acknowledging that the teaching is on the wane, he declares: 'After you [his disciples] have died, the Dharma will flourish again' (汝等死後, 法當更興; GSZ, p398a22). ${ }^{63}$

Occasionally, the prognostication does not concern the Buddhist teaching in its entirety, but rather the development of specific Buddhist schools of thought. One example is the 'Consciousness Only' (wéishi 唯識) thought that was promoted by the translator Paramārtha (Zhēndì 真諦; 499-569). According to the XGSZ, his philosophy and the scriptures he translated were initially disregarded and even criticised by court officials during the Chén 陳 Dynasty (557-589). Nevertheless:

Paramārtha pointed with his finger to the northwest and said: 'In this region there is a great country, which is neither close by nor far away; after we have passed away, [my teaching] shall flourish and spread there. But we will not witness its rise, and this I regard as greatly regrettable [lit. "to make a great sigh"].'

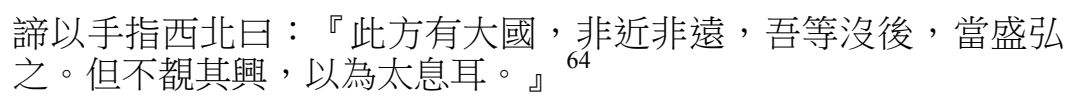

(XGSZ, p430c11-13)

Predictions based on the main tenets of Buddhist teaching feature in a number of the biographies. For instance, Bóyuăn's 帛遠 (206?-305?) entry in the GSZ contains explicit references to the power of one's actions (yè 業; 'karma') and the way in which good and bad deeds determine one's destiny:

[Bóyuăn $]^{65}$ unexpectedly addressed the followers of the path and the disciples, saying: 'In a few days, the [karmic] response [to my actions] will arrive. ${ }^{66}$ Then he took his leave [...] The following morning, he visited the high official [Zhāng]fú and talked to him, then suddenly disagreed with one of the official's suggestions, and the official issued a punishment. The entire assembly was bewildered and sighed in regret.

${ }^{63}$ The Emperor Tài Wŭ 太武 of the Northern Wèi ordered Xuángāo's execution in 444. Prior to his death, on several occasions the monk reportedly predicted the persecution of China's Buddhists between 446 and 452 and the consequent decline of the Buddhist Dharma (see GSZ, p398a1-8; and Lidài sānbăo jì 歷代三寶紀; CBETA: T49, no2034, p85a27-b3). For more on Xuángāo, see Lai 2003: 143-161.

${ }^{64}$ According to the XGSZ, Paramārtha's teaching only gained popularity during the Suí Dynasty, when it was promoted by the monk Tánqiān 昙遷 $(542-607)$, among others. Tánqiān fled to the south during the Northern Wèi suppression of Buddhism, came into contact with Paramārtha's Mahāyāna-saṃgraha (Shè dàshèng lùn 攝大乘論), and eventually settled in Cháng'ān in 587.

${ }^{65}$ This monk is also known as the 'Dharma Patriarch Bó' (Bó făzǔ 帛法祖).

${ }^{66}$ Here, dui 對 is used in the sense of bàoying 報應: that is, retribution for actions performed during one's lifetime. Indirectly, this indicates his impending death. 
Dharma Patriarch [Bó] (帛法祖) said: “As for my encountering this final response to my actions, those from the previous lives are already concluded, and are not today's matter.' He then called out for the Buddhas of the Ten Directions, and said: 'As for the causes of the sins of my previous rebirths, I would like to finish their karmic effect [by being killed now]. ${ }^{67}$ And I vow that from now on, I will regard [Zhāng]fŭ as a good friend [i.e. teacher], and not let him receive the sin of killing me.' Consequently, he was whipped 50 times and died immediately.

忽語道人及弟子云：『我數日對當至。』便辭別。……明晨詣輔 共語, 忽忤輔意, 輔使收之行罰。眾咸怪惋。祖曰：『我來此畢 對，此宿命久結，非今事也。』，乃呼十方佛：『祖前身罪緣， 歡喜畢對。願從此以後, 與輔為善知識, 無令受殺人之罪。』遂 便鞭之五十，奄然命終。

(GSZ, p327a28-b6)

In another story featuring the monk Zhìzàng 智藏 (458-522), there is an account of a woman who excelled in physiognomising. ${ }^{68}$ She predicted that Zhìzàng's

brightness and rhetorical skills will spread throughout his generation, and his fame will circulate around the world. But, unfortunately, his lifespan will not be long, and he will reach only the age of 31 .

聰辯蓋世，天下流名。但恨年命不長，可至三十一矣。

(XGSZ, p466a24-26)

On hearing this, Zhìzàng

exhausted his energy to practise the Way, and took the great vows [of a bodhisattva]; satisfied with that, he did not try to go out of the gate [i.e. did not engage in teaching others]. He then explored the canon of scriptures, and attained the adamantine wisdom [i.e. the Diamond Prajñ $\bar{a}-$ pāramitā sūtra], which he memorised and recited, and revered until the end of his life.

竭精修道, 發大誓願, 足不出門。遂探經藏, 得金剛般若, 受持 讀誦, 畢命奉之。

(XGSZ, p466a26-28)

As a result of his reverence to and study of this scripture, Zhìzàng escaped the fate of dying at a young age and finally passed away at 65 . This passage neatly illustrates the power of Buddhist scriptures because Zhìzàng's engagement with a single text ultimately modifies a prognostication relating to his lifespan.

${ }^{67}$ That is, Bó uses the official to end the negative karmic influence of his former lives. As a consequence, Zhāngfǔ, despite killing Bó, will not receive any negative retribution for the deed.

${ }^{68}$ See Campany 2012: 40 and Jensen 2018: 334-355 on non-Buddhist diviners, such as spirit mediums and physiognomists, in Buddhist historical literature. 


\subsubsection{Buddhist Material Culture}

Predictions concerning Buddhist scriptures, monasteries, and images feature regularly in the GSZ and XGSZ. For example, in Făyì's 法意 (?-?) biography, there is a prediction of the destruction and restoration of the Yánxián 延賢 Monastery: ${ }^{69}$

[Făyì built the Yánxián Monastery.] Later, [the monk] Bēidù left and came to this monastery, saying: "This place will soon experience all kinds of anomalies; afterwards, this should change for the better; the place [i.e. the location of the monastery] is facing the "heavenly halls" [i.e. probably, an easterly direction], ${ }^{70}$ [and] it is easy to perform meritorious actions here.' And unexpectedly [the monastery] was [indeed] burned by wild fires. Later, Qí Xié, Zhāng Yǐn, and others relied on the guidance of Bēidù, as is recorded in the Biography of [Bēi] $\dot{u}^{71}{ }^{71}$ and they went together with [Fă]yì to the mountains and wished to restore [the monastery].

後杯度去來此寺, 云：『此處尋有諸變，後時當好，地對天堂， 易為福業。』俄為野火所燒。後齊諧及張寅等, 藉杯度之旨, 語 在度傳, 乃與意共行山地, 更欲修立。

(GSZ, p411a26-29)

Predictions relating to the restoration or rebuilding of monasteries are also found in the entries for Huilì 慧力 (?-?; GSZ, p410a17-b10), Chán Master Fótuó 佛陀 (439531; XGSZ, p551b10-13), Ācārya Cén (Cén shélí 岑闍梨; ?-?; XGSZ, p661a411), and others.

Dàojī’s 道積 (568-636) biography includes a reference to a large but unfinished statue of the Buddha. After receiving a request to complete the statue, the monk has a dream: ${ }^{72}$

${ }^{69}$ This famous monastery is located in Jiànkāng 建康 (modern-day Nánjīng 南京), the capital of the Eastern Jìn and the Southern Dynasties. It was founded at the beginning of the 5th century and continued to prosper until the end of the Southern Dynasties period (see Náncháo sì $k \breve{a} o$ 南朝寺考; CBETA, B14, no86, p650a10-651a1).

${ }_{70}$ Dì duì tiāntăng 地對天堂 probably has a geographical meaning here, with tiāntăng ('heavenly hall') not referring to a structure in the imperial palace, but more generally to an auspicious location in geomancy. According to the Dill $\bar{x} \overline{i n s h} \bar{u}$ 地理新書, it may denote an easterly direction. However, this interpretation is based on later sources (e.g. Xü xiū sìkù quánshū, cè 1054: 89) and may not necessarily reflect the intention of the compiler of the GSZ. As such, the precise meaning of the passage remains uncertain.

${ }^{71}$ In Bēidù's biography, he tells Qí Xié and the others: 'In this year there will be a major disaster, you should ardently cultivate meritorious deeds. The monk Făyì is a man of great virtue, you should go to him and rebuild the destroyed monastery in order to avert disaster' (年當大区, 可懃修福業。法意道人甚有德，可往就其修立故寺，以禳災禍也; GSZ, p392a25-27).

${ }^{72}$ For a discussion of this episode that explores the dream imagery from the standpoint of traditional Chinese oneiromancy, see Jensen 2018: 208. 
The evening he received the request, he dreamed that there were two lions at the side of a precipice, and next to a large statue they spit out precious pearls one after the other, continuing without interruption.

受請之夕, 寢夢崖傍見二師子, 於大像側連吐明珠, 相續不絕。 (XGSZ, p696b3-4)

Dàojī interprets his dream as follows:

The king of hunting [i.e. the lion] is sovereign [i.e. independent]; this expresses that the Dharma is flowing without impediment; the precious pearls gushing forth by themselves is a metaphor for the donations being inexhaustible. The mysterious activity is secretly revealed[, which means that] there will be success this time.

狩王自在, 則表法流無滯; 寶珠自涌, 又喻財施不窮。冥運潛 開, 功成斯在。

(XGSZ, p696b5-6)

As these examples clearly show, predictions could be made about material objects and Buddhist institutions as well as human destinies and accomplishments.

\subsubsection{Predictions relating to Chinese Topics and Methods-Involvement with Politics and the State}

Initially, at least, Buddhism was a foreign religion in China, so practitioners had to rely on support from the secular powers in order to gain acceptance and spread the teaching. The relationship between Buddhists and the state intensified during the Northern and Southern Dynasties period, so, understandably, the GSZ and XGSZ contain many predictions relating to the fortunes of rulers and their realms. In Kumārajīva's biography, for example, there is a passage on Lü Guāng 呂光 (338-399), an emperor of the Later Liáng 後凉 Dynasty. The famous translator warns the King of Kucha that Lü Guāng is about to invade his kingdom and recommends submission to his powerful army:

'The fortunes of the state are about to decline, and there will be a strong enemy coming from the east in a few days, and you should receive them respectfully, do not resist their vanguard.' [Bái]chún did not heed his advice and fought the army, and [Lü] guāng subsequently destroyed Kucha and killed [Bái]chún.

\section{『國運衰矣，當有勍敵日下人從東方來，宜恭承之，勿抗其鋒。』 純不從而戰, 光遂破龜䒺茲殺純。}

(GSZ, p331b29-c1)

The entry for Huì'ān 慧安 (a monk who was active during the 4th century) includes a prediction that the Early Qín 秦 Dynasty (351-394) of the Fú 苻 family will flourish. Huiān obtained a staff originally owned by an Indian monk that was inscribed with 
Indic letters. No one was able to decipher the inscription until it was shown to Kumārajīva, who translated it as follows:

Originally born in Sālavana of India. When there is disorder in the southern region, 'căo fú' 草付 will rise, and later ensure that the teaching of the Dào [here: Buddhism] of Kumāra[jīva] will prosper.

本生天竺娑羅林。南方喪亂草付興, 後得羅什道教隆。

$$
\text { (GSZ, p370a27-28) }
$$

If one combines the upper part of the character 草 (i.e. the 'grass radical') with the character 付, the resulting character is Fú 苻—a reference to the founder of the Early Qín Dynasty, Fú Jiàn 苻健 (317-355), who adopted the title Gāozŭ 高祖 on becoming emperor. As such, Kumārajīva predicts the family's rise to power and, consequently, the dissemination of his own teachings.

Huìyì's 慧義 (372-444/445) biography addresses Liú Yù’s 劉裕 (363-422) founding of the Liú Sòng 劉宋 Dynasty (420-479), which superseded the Jìn 晉 Dynasty. In this entry, a monk by the name of Făchēng 法稱 (?-?) from Jìzhōu 冀州 informs his student Pŭyán 普嚴 that he has recently encountered a benevolent spirit:

The spirit of Mt. Sòng said the following: 'In Jiāngdōng there is a general Liú who will certainly receive the Mandate of Heaven; I take 32 jade rings ${ }^{73}$ and one plate of zhen gold as a token of faith [in this prediction].'

嵩高靈神云：『江東有劉將軍，應受天命，吾以三十二璧、鎮金 一鉼, 為信。』

(GSZ, p368c6)

Further references to the establishment of new dynasties include Sēnghán 僧含 (416-484) foretelling General Liú Jùn's 劉駿 $(430-464)$ accession to the throne ${ }^{74}$ (GSZ, p370b25-28) and Făshī 法施 (586-701) predicting that General Xiāoxǐ 蕭銑 (583-621) will become the King of Bālíng 巴陵 (in the eastern part of Sìchuān; XGSZ, p663c27-28). There are also several predictions pertaining to revolts and wars. $^{75}$

In addition to predictions relating to the personal destinies of monks and secular rulers, prognostications of events that will affect whole regions, such as natural disasters, feature prominently in the GSZ and XGSZ. For instance, Zhú Făhuì's

${ }^{73}$ The figure 32 probably hints at the duration of the dynasty.

${ }_{75}^{74}$ Liú Jùn ruled as Emperor Xiào Wǔ 孝武 of the Sòng 宋.

${ }^{75}$ The GSZ contains predictions of revolts in the entries for Kumārajīva, Gunabhadra (394-468), Xuáncháng 玄暢 (416-484), Fótúchéng 佛圖澄 (?-348/349), Băozhì 保誌 (418515), and Făyuàn 法願 (414-500/501). The XGSZ has similar predictions in the entries for Zhuănmíng 轉明 (?-?), Jiăyì 賈逸 (518-610), and others. On predictions relating to impending wars, see, e.g. the GSZ entries for Kumārajīva, Fótúchéng, and Făjìn 法進 (?-?). 
竺法慧 (287?-344?) biography includes a prediction of a major flood occurring as a consequence of his death: ${ }^{76}$

'Three days after my death, there will be violent rainfalls.' When that time came, there was indeed flooding; at the city gate the water stood one zhàng deep, and the inhabitants were floating and submerged in it, and many of them died.

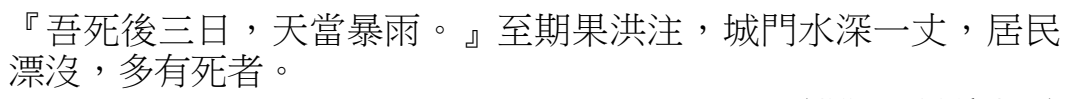

(GSZ, p389b4-5)

Likewise, we are told that a series of natural disasters followed Huì'àn's 慧岸 (533623 ) death. However, it is unclear whether the monk's foreknowledge of these disasters prompted him to commit suicide, or whether they were triggered by his passing:

In the 6th year of the Wŭdé era (623), [Huiān] suddenly repeatedly cried bitterly and was unable to control himself, saying: "Who could tolerate seeing such things?' Based on that, he submerged himself in a lake and sought death, but the [members of the] assembly attempted to enter the lake in order to save him. However, [Huì'ān] sat on the bottom of the lake and had already passed away [when they reached him]. In the year he died, there was a severe drought and no harvest, and those who died due to epidemics were numerous.

武德六年, 輯復悲泣不能自禁, 曰：『誰能見煩惱？』因沒水求 死, 眾人爭入水接之, 乃端坐水底已卒。卒後, 其年元早不收, 疫死眾矣。

(GSZ, p664a16-18)

Hence, the death of a famous monk can resonate throughout the cosmos and cause nature to 'mourn' and initiate potentially dangerous and sometimes even disastrous consequences for those left behind. This correlates perfectly with contemporary thinking relating to the demise of high-ranking laypeople, such as emperors. It is probably no coincidence that the compilers of the Buddhist history texts drew on these notions to emphasise the significance of eminent monastics.

\subsection{Traditional Chinese Prognostication Methods in the GSZ and XGSZ}

\subsubsection{Prognostication Based on the Zhōuyì 周易}

In general, as the previous examples have demonstrated, there is no mention of mantic techniques when the GSZ and XGSZ introduce the subject of prognostication. Rather, the texts tend to present predictions as 'by-products' of eminent monastics' outstanding

${ }^{76}$ This correlates with ancient Chinese beliefs relating to the stimulus-response cosmology. On the notion of the 'readable cosmos' as a trope in early Chinese historiography, see Li 2007. 
virtue and insight, which grant them a superior form of knowledge. That said, there are occasional references to specific techniques.

One type of prognostication is based on the Zhouyì 周易 (i.e. the Yìjing 易經; Book of Changes), ${ }^{77}$ which in its current form consists of two parts. The jīng 經 part consists of 64 hexagrams (guà 卦) and 384 lines (yáo 爻). Each hexagram has a name, an image, a divinatory explanation of the hexagram itself, and another explanation of the lines attached to it. The so-called 'commentary' (zhuàn 傳) section, which is traditionally attributed to Confucius's disciples, contains further comments on the hexagrams and lines. During divination, the practitioner should

first use milfoil stalks in order to seek a number (shù 數), and obtain a number in order to determine the lines (yáo), and multiple lines then form a hexagram (guà); based on the hexagram, a 'sentence' ( $c i$ 辭) is produced.

先用著以求數, 得數以定爻, 累爻而成卦, 因卦以生辭。 (Zhōuyì zhèngyì 周易正義, Shisān jīng zhùshū: 13) ${ }^{78}$

References to milfoil divination occur quite frequently in the GSZ and XGSZ. For instance, in the biography of Zhú Fătài 䇥法汰 $(320-387 / 388),{ }^{79}$ two of his disciples are said to have received 'extensive training in the meaning of the sütras, while also excelling in the Lăozl and Yỉjing' (汰弟子昙一、昙二, 並博練經義, 又善老易; GSZ, p355a13-14). Similarly, Făyuàn’s 法願 (414-500/501)

family originally served the spirits, and he himself practised drumming and dancing [i.e. shamanistic rituals], various worldly skills, prognostication with milfoil stalks (shīyáo 者爻), and physiognomising; all [of his skills] were utterly remarkable.

家本事神，身習鼓舞，世間雜技，及者爻、占相，皆備盡其妙。

(XGSZ, p417a1-2)

Nevertheless, milfoil prognostication is only ever mentioned in a generic way, and neither text elaborates on the theme.

${ }^{77}$ Zhouyyi jíjiě; on that work, see, e.g. Karcher 2002 and Davis 2012.

${ }^{78}$ Specifically, one should take fifty stalks of milfoil, then, after a threefold calculation process, one can determine the nature of the lines (whether they are yin or yáng). One hexagram consists of six broken (yīn yáo 陰爻) or unbroken (yáng yáo 陽爻) lines, so the calculation has to be performed six times in order to arrive at a hexagram. The auspiciousness or inauspiciousness of an event is determined on the basis of one's interpretation of the 'sentence' associated with the hexagram and the lines.

${ }^{79}$ Zhú Fătài was active during the Eastern Jìn period (second half of the 4th century). Originally a fellow student of the famous Dào'ān 道安, he became a specialist in early Chinese prajñ $\bar{a}$ philosophy (GSZ, p354b29, 354c21-23). 


\subsubsection{Physiognomising (xiàng)}

Physiognomising, which involves making predictions on the basis of a person's features (xiàng rén shù 相人術), seems to have been a common practice in medieval India (see above) and China. There are certainly ample references to the technique in preBuddhist Chinese sources. ${ }^{80}$ However, whereas passages relating to xiàng rén 相人 ('physiognomising persons') in the Buddhist translated literature tend to focus strictly on physical features, the Chinese sources suggest that the colour of the face, the voice, ${ }^{81}$ and even aspects of a person's behaviour, character, and mental state could also be taken into account when making predictions. There are several references to monastics employing physiognomising techniques in the GSZ and XGSZ. ${ }^{82}$

\subsubsection{Topomancy}

Topomancy - that is, prognosticating on the basis of the physical environment or particular topographical features - had been practised in China since time immemorial. For example, the Zhouyi 周易 states:

In ancient times, when Páo Xī ruled the world as king, he looked up to observe the patterns in Heaven, and he looked down to observe the rules on Earth; he observed the patterns of birds and beasts, and how these fitted with the Earth [...] Subsequently, he created the Eight Trigrams.

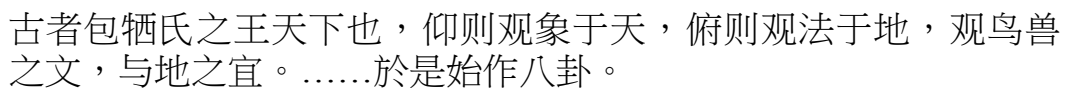

(Shisān jīng zhùshü: 86)

It was thought that the natural environment played a crucial role in the well-being of its inhabitants, and that it could determine the success or failure of their endeavours. From the Hàn Dynasty onwards, topomancy focused on foretelling fortune or misfortune on the basis of the location and architectural features of a person's home. For example, the Lùnhéng 論衡 (Chapter Sì hui 四諱) insists that a western orientation is inauspicious. ${ }^{83}$

\footnotetext{
${ }^{80}$ See, e.g. Zuǒzhuàn 左傳, which records the official Shūfù 叔服 physiognomising the two sons of Gōngsūn Áo 公孫敖 (Shísān jīng zhùshiu: 1836).

${ }^{81} \mathrm{Cf}$. Xúnzĭ: 'When [he] physiognomised the bodily features (xíngzhuàng 形狀) and facial colour/features (yánsè 顏色) of a person in order to know whether their fortune would be good or bad, auspicious or inauspicious' (相人之形狀、顏色而知其吉凶、妖祥; Xúnž 荀子; Chapter Fē $\bar{i}$ xiàng 非相; Xúnzí jijiě: 72). The Xiàng shū 相書 mentions physiognomising of the eyes, nose, ears, and other parts of the body. In addition, prognostications could be made based on a person's way of walking, the timbre of his voice, and so on (Míng kānbĕn Yimén guăngdú, cè 9).

${ }^{82}$ See, e.g. the biography of Zhìming 智命 (529-621; XGSZ, p683a15).

${ }^{83}$ Lùnhéng jiàoshì: 968. In the Zháijing 宅經 (Classic of residences), edited by Zhōu Lüjìng 周履靖 during the Míng Dynasty, this idea is rationalised as follows: 'Therefore, the residence is the "origin" of a person. A person makes a residence his home, and if his dwelling there is peaceful, then the [subsequent] generations of his family will be prosperous; if it is not peaceful, then his clan will decline. The same is true for graves in terms of their situation at rivers and on mountains.'
} 
Our historical sources suggest that many monks excelled in the art of topomancy. In the GSZ and XGSZ, topomantic prognostication centres on identifying underlying patterns in the local ecosystem. For instance, in Jìngyuān's 郬淵 (543-611) biography, his teacher Língyù 靈裕 (517-605) attempts to identify a topographically auspicious location for a new temple:

[Líng]yù prognosticated ( $b \check{u} 卜$ ) the northwestern hill, and called it 'blissful land'. It is not only that the group of mountain hermits [i.e. monks] will succeed each other; it will also mean that the donations will not decline. [Jìng]yuān then directly followed his advice. This is the very foundation of the monastery today. More than 50 years have passed since that time [when the monastery was constructed]. Some inauspicious years have occurred during this period; however, donations to the monastery have continued without interruption.

裕卜西南坡阜, 是稱福地。非唯山眾相續, 亦使供擬無虧。淵即 從焉, 今之寺墌是也。自爾迄今五十餘載，凶年或及, 而寺供無 絕。

(XGSZ, p511c18-21)

In Dàobiàn's 道辯 (?-?) biography, an unidentified person asks the monk to choose a suitable place for his grave, whereupon Dàobiàn

inspected the hills and plains, and, pointing at one location, said: '[You should] install your grave mound here, [as this will cause your descendants to] have sufficient food and riches.'

巡歷峴原，示其一所，曰：『此中安墓，足食豐財。』

(XGSZ, p662b23-24)

\subsubsection{Observing Celestial Phenomena}

In the GSZ and XGSZ, a number of monks make significant predictions after observing celestial, meteorological, or atmospheric phenomena. ${ }^{84}$ For example, Ān Shìgāo 安世高 (GSZ, p323a26), Kumārajīva (GSZ, p330c10), Kāng Sēnghuì 康僧會 (GSZ, p325a16-17), Guṇabhadra (GSZ, p344a7), Sēnghán (GSZ, p370b14-15), Tánkējiāluó 昙柯迦羅 (*Dharmakāla; GSZ, p324c17-18), Tánguāng 昙光 (GSZ, p416b1516), Sēngfàn 僧範 (XGSZ, p483b21-22), and Shànhuì 善慧 (XGSZ, p688b8) are all credited with this ability. When Dàobiàn notices that the moon is approaching the Well Constellation (jüng sù 井宿), ${ }^{85}$ he says: 'There is an event in the Western Chŭ;

故宅者, 人之本。人以宅為家, 居若安, 即家代昌吉; 若不安, 即門族衰微。墳墓川岡、並 同兹説。(Yǐngyìn Wényuān gé Sìkù quánshū, cè 808: 8).

${ }^{84}$ These phenomena also play an important role in non-Buddhist literature (see e.g. Chapter Yìwén zhi 藝文志 in the Hànshü: 1763-1765).

${ }^{85}$ The Well Constellation, also known as the 'Eastern Well' (dōngjĭng 東井), one of the seven constellations of the south, is often associated with floods in traditional Chinese astronomy/astrology (see e.g. Shüji: 1302). For astrology and divination in ancient China, see Cullen 2011 
one should inform monastics and laypeople that they should prepare for flooding' (于時月臨井宿, 便云：『事在西楚, 可告道俗, 宜營水備』; XGSZ, p662c1213). Furthermore, he predicts that the Hàn River will rise rapidly and inundate the city of Xiāng, and that the dry moat (huáng 隍) under the city wall (chéng 城) will soon be full of water.

In another passage, we learn that meritorious deeds can overturn the pernicious influence of celestial phenomena. The Emperor Jiănwén 簡文 (320-372) of the Eastern Jìn 晉 Dynasty (265-420) asks Zhú Făkuàng 䇥法曠 (327-402) about some seemingly ominous stars and is told that practising virtuous government will transform impending disaster into good fortune (GSZ, p356c21-24).

Monks also foretell the future through observation of atmospheric phenomena, such as clouds and wind. Kumārajīva, for example, predicts a rebellion after feeling an inauspicious wind (不祥之風, 當有㚣叛; GSZ, p331c17-18). This technique was deeply rooted in traditional Chinese culture. ${ }^{86}$

\subsubsection{Selecting Appropriate Times}

In China, the timing of important events and actions had long been viewed as critical for their success. The Lùnhéng explains this concept in detail:

When commencing a project, moving home, engaging in rituals, funerals, work tasks, assuming office, marrying, if one does not select an auspicious day, and does not avoid the [inauspicious] spirits of the year and spirits of the month, then one will encounter demons and meet spirits, and during these turbulent times [i.e. when men and spirits meet], one will be hurt by them. Therefore, one will meet with disease or generate misfortune, get entangled with the law and be indicted with a crime, to the extent of being killed and [seeing] one's family exterminated; all [because] one does not value caution and makes the mistake to have contact [with spirits] during the taboo days.

起功、移徒、祭祀、喪葬、行作、入官、嫁娶, 不擇吉日, 不避 歲、月, 觸鬼逢神, 忌時相害。故發病生禍, 絓法入罪, 至於死 亡, 殫家滅門, 皆不重慎, 犯觸忌諱, 之所致也。

(Lùnhéng jiàoshì: 1008)

Therefore, it was deemed imperative to consult a lipǔ 歴譜 ('calendar chart') prior to scheduling any major event or undertaking. There is an early reference to a lipǔ in the Hànshū (Chapter Yìwén zhi 藝文志):

As for [using] the calendar chart, [one] arranges the four seasons in the right order, confirms the solar terms of equinox and solstice, and calcu-

and 2017, and Pankenier 2013. For Buddhist astrology during the Táng Dynasty, see Kotyk 2017a. For the relationship between Indian/Iranian and Chinese astrological techniques, see Mak 2014 and 2015, and Kotyk 2018.

${ }^{86}$ See Chapter Chūnguān zōngbó 春官宗伯 in Zhōulı̆ (Shísān jīng zhùshūi: 819-820). 
lates the confluence of the sun, the moon, and the five stars [of Metal, Wood, Water, Fire, and Earth] in order to investigate the effect of cold and heat and of death and life. Therefore, the sagely king carefully calculates the calendric numbers in order to fix the regulation of the colours of the vestment of the Three Reigns (sān tǒng 三統), and in order to investigate the confluence of the five stars, the sun, and the moon. Grievance over inauspicious failures and joy over auspicious successes [as well as] the art [of predicting them] all come out of this [i.e. selecting times according to the calendar chart].

\section{歴譜者，序四時之位，正分、至之節，會日月五星之辰，以考寒 暑殺生之實。故聖王必正歴數, 以定三統服色之制 ${ }^{87}$; 又以探知五 星日月之會，凶阨之患，吉隆之喜，其術皆出焉。}

(Hànshū, juàn 30: 1767)

The GSZ and XGSZ contain occasional references to monastics' ability to select auspicious dates. ${ }^{88}$ For instance, Qiúnàpídì 求那毘地 (*Gunavṛddhi; 403-502) ${ }^{89}$ reportedly excelled in this technique (GSZ, p345a27), as did Shànhuì (497-569; XGSZ, p688b8) and Făyùn 法運 (567-627; XGSZ, p664a20).

\subsubsection{Manipulating the Cosmic Board (shizhàn 式占)}

Along with predictions based on milfoil, manipulation of the shizhàn 式占 ('cosmic board') was one of the main methods of prognostication in medieval China. ${ }^{90}$ However, this was not a uniform technique; rather, a square board that symbolically represented the cosmos was manipulated and interpreted in a variety of ways.

It seems that shizhàn prognostication was closely related to astronomical and calendrical divination methods. Typically, the upper part (yuánpán 圓盤) of the board depicted Heaven, with the Great Dipper in the centre, surrounded by the twenty-eight stellar constellations and the spirits of the twelve months. The Earth was depicted in the centre of the lower part (fängpán 方盤), surrounded by the Heavenly Stems and Earthly Branches (tiāngān dizhñ 天干地支) that were related to the calendrical system.

${ }^{87}$ Sāntŏng 三統 is a term based on Dŏng Zhòngshū’s 董仲舒 (179-104 BCE) philosophy. It denotes the three months that can be determined by the initial month of a year (zhèngyuè 正月) according to the Chinese lunar calendar. In Dŏng's system, specific seasons, colours, and other features can be correlated with the respective months. Each new dynasty has to determine the appropriate beginning of the year.

${ }^{88}$ The Northern Chán monk Yīxíng 一行 (683-727) played a crucial role in propagating the lipŭ in Chinese Buddhism. He composed several works on calendric sciences, especially after coming into contact with the Indian Esoteric Buddhist master Śubhakarasiṃha, and constructed a device to measure the movement of the stars. For more information, see Jeffrey Kotyk and Michael Radich's entry for lìpŭ in the DDB and the Xìn Táng shü: 1548.

${ }^{89}$ A monk from southern India who translated Buddhist texts in the Nánjīng area towards the end of the 5th century. For more information, see Chavannes 1962: Vol. 2, 14-149.

${ }^{90}$ See Steavu 2018 for a study and schematic illustrations (pp. 200 and 203) of the shi board in the context of medieval Taoism and Buddhism. See also Lǐ 1993 and Harper 1979. 
The Shiji (p3218), compiled in the 2nd century BCE, mentions the shizhàn, and it was clearly still a common device more than half a millennium later, as the XGSZ credits several monks - including Língyòu 靈祐 (XGSZ, p497c24-28) and $\bar{A} n l i ̄ n$ 安㡹 (XGSZ, p480b9)—with mastering its use for divination purposes. However, it does not feature in any specific stories.

\subsubsection{Consulting Apocryphal Texts}

The GSZ and XGSZ mention the túwěi 圖緯 ('charts and wefts') 91 technique on several occasions. This term seems to be synonymous with chènwěi 讖緯 and túchèn 圖 讖, and usually refers to the so-called 'apocryphal texts'. Scholars of these texts frequently made predictions based on their interpretations of them. The ideas contained within the apocrypha were attributed to Confucius himself, so they possessed great authority. The GSZ and XGSZ report that some Buddhist monks were adept at using the texts to predict the future. Tánkējiāluó (*Dharmkāla; ?-?), an Indian Vinaya specialist who arrived in Luòyang in the middle of the 3rd century, supposedly

excelled in the four types of Vedic literature and [predictions based on] wind, clouds, stars, and the apocrypha; as for a change of fortune, there was none he did not know thoroughly.

\section{善學四圍陀論。風雲星宿圖識運變莫不該綜。}

(GSZ, p324c17-18; emphasis added)

Meanwhile, several other entries include more generic references to these skills in order to illustrate the supernatural talents of the monk in question. For instance, Kumārajīiva reportedly had 'exhaustive [knowledge of] yīn and yáng, ${ }^{92}$ the stars, and calculations ${ }^{93}$ (陰陽、星、算莫不必盡; GSZ, p330c10), while Qiúnàpídì is credited with 'understanding yinn and yáng' (明解陰陽; GSZ, p345a27), and Dào'ān had a comprehensive grasp of 'yīn and yáng and the calendar calculations' (陰陽、算數， 亦皆能通; GSZ; p352c15-16). A monk is sometimes even accorded equal respect

${ }^{91}$ This term also appears in the Hòu Hànshū (p3037); see Cullen 2017: 229, 313. On chènwěi 'apocrypha' and related terms, and their significance in late imperial China, Cullen writes: 'Typically, such texts were taken as embodying an esoteric tradition that Confucius and his successors had not seen fit to include in the received classics, but had handed down by other means. Modern scholarship holds that such texts were not in fact ancient, but originated around the beginning of the Common Era, probably in the period of political and ideological conflict from the end of Western Han, through the rule Wang Mang, to the early Eastern Han. Their titles are usually based on those of the received classics, and their contents may contain references to the calendar, heavenly bodies, or matters relevant to astronomical systems, as well as words of prophecy that were clearly meant as references to current events' (Cullen 2017: 229). On prognostication in the wěish $\bar{u}$ 偽書 literature, see also Nielsen 2018.

${ }_{92}$ Yìn and yáng, the two primordial forces in the cosmos, are often mentioned in the context of prognostication. If they are not in harmony, disaster might ensue. The hexagrams of the Yijing/ Zhōuyì can be divided into those belonging to yin and those associated with yáng.

${ }^{93}$ Here, suàn and suànshù are used as generic terms for a variety of techniques involving calculations (e.g. astronomical, calendric, or those relating to bù $卜$ prognostication). 
for his prognostication skills and his knowledge of the Buddhist texts, as in the following passage on Fă'ài 法愛 (?-?): 'He understood the sütras and the śāstras, and the art of calculation' (解經論兼數術; GSZ, p376c3).

\subsubsection{Prognostication Based on the Sound, Shape, and Meaning of Chinese Characters}

Whereas predictions in texts translated from Indic sources are quite straightforward, they were sometimes transformed into 'riddles' or word games in the Chinese context, frequently based on particular features of the Chinese writing system and the methods of indicating the sound and meaning of specific characters. ${ }^{94}$ As such, the meaning may be 'hidden' and must be retrieved by tracing the mechanisms through which it was encoded.

The Chinese language itself, especially in its written form, was sometimes used to predict the future. For example, during a revolt of the Pí 鄆 people in Yìzhōu 益州 Province, the monk Sēngdù 僧度 was asked to predict the rebellion's chances of success:

[Sēngdù] took his brush and wrote down two characters, 州度. The insurgents said with delight: 'The province (zhōu 州) will be passed over (dì 度) to us, this is certainly auspicious!'

(XGSZ, p657b26-28)

The revolt was crushed, yet Sēngdù's prediction was accurate. The fault lay with the rebels, as they interpreted 州度 semantically rather than phonetically. In Early Middle Chinese 州 is read as $t 6 u w$, and 度 can be read as either $d o^{h}$ or $d a k$. When interpreted as fănqiè 反切, ${ }^{95}$ one takes the initial /tc/ and combines it with the rime part $a k$, resulting in t6(i)ak, which is near-homophonous to tciak 斫 ('break; cut off'). When using the phrase as reversed fänqiè (= 度州), the result would be tuw, which is very close to the reading tow ('head'). (Indeed, the readings might have been identical in the local dialect.) As such, the phrase is 'properly' interpreted as 斫頭 ('to cut off the head'). ${ }^{96}$

In the previous example, the focus is on playing with conventions for expressing the reading of a character (fănqiè), but in other instances the specific meaning of a character is ignored and rather interpreted as a homophonous or near-homophonous word. ${ }^{97}$ Or, occasionally, an omen is misinterpreted on the basis of (false) resemblance.

\footnotetext{
${ }^{94}$ This form of wordplay in the prognostication literature has considerable antiquity. For some cross-cultural examples (drawn from the context of oneiromancy), see Noegel 2007.

${ }^{95}$ The fănqiè system was used from the 4th century to indicate the reading of Chinese characters. The reading was given by combining two characters, with the first representing the initial (shēngmú 聲母) and the second the remaining part (the so-called rhyme part, yùnmŭ 韻母 + tone).

${ }^{96}$ This form of interpretation can be traced back at least as far as the Zuǒzhuàn, as discussed at length in Li 2007.

${ }^{97}$ The use of phonetic loan characters was an important feature of the pre-modern Chinese writing system throughout its history, particularly in less formal or vernacular writing.
} 
For instance, the biography of Língyù (518-605), a proponent of the Dilùn 地論 School, contains the following passage:

The foundations of the hall in which Xuē Zhò ${ }^{98}$ was residing suddenly turned into jade. [Xuē] Zhòu interpreted this as a good omen and provided a vegetarian meal in order to celebrate it. [However,] [Líng]yù said: 'This [is not jade but] glass [liúli 琉璃; i.e. a cheap material], and it is appropriate to be careful and caution against it; it is advisable to pray to avert [the inauspicious] with good fortune.' [Xuē] Zhò did not heed his words and afterwards Yáng Liáng ${ }^{99}$ launched a rebellion; the matters [of the omen and the rebellion] were related to each other by cause and effect, and [Xuē Zhòu] was consequently banished to a remote area.

薛䡒所住堂礎忽變為玉。㫣謂為善徵也, 設齋慶之。裕曰：『斯 琉璃耳, 宜慎之戒之, 可禳之以福。』䡒不從其言, 後楊諒起 逆, 事有相緣, 乃流之邊裔。

(XGSZ, p496c15-19)

Similarly, in Fótúchéng's (?-348) biography:

[Shí]hŭ used to sleep during the daytime, and in his dream he saw a flock of sheep carrying fish on their shoulders while coming from the northeast [i.e. the homeland of the Xiānbēi]. On waking, he consulted with [Fótú]chéng [who said]: 'This is not auspicious, the Xiānbēi will come into possession of the Central Plain!'

虎嘗書寢, 夢見群羊負魚從東北來, 寤以訪澄。澄曰：『不祥 也，鮮卑其有中原乎。』

$$
\text { (GSZ, p386b1-3) }
$$

In making his prediction, Fótúchéng combines the characters for yáng 羊 ('sheep') and yú 魚 ('fish') from Shíhǔ's dream in the compound character xiān 鮮, as in Xiānbēi 鮮卑 (*S[a]r-pe) — a Nomadic tribe that invaded northern China and eventually established the Northern Wèi 北魏 Dynasty (386-534).

Băozhì's biography includes a story of an official by the name of Húxié 胡諧 falling ill (GSZ, p394b10-13). Asked to cure the official, Băozhì writes the two characters míng $q \bar{u}$ 明屈 on a piece of paper. Húxié's fellow officials are unable to interpret this message (which semantically makes no sense), and Húxié passes away the next day. Băozhì then reveals the hidden message and informs the officials that 明屈 should have been interpreted as: 明日將死 ('He is going to die tomorrow'). While the original meaning of 屈 is 'bent, crooked', Băozhì 'decomposes' the character into its two structural parts $s h \bar{\imath}$ 尸 and $c h \bar{u}$ 出 (i.e. 'a corpse emerges').

\footnotetext{
${ }^{98}$ Xuē Zhòu 薛䡒 (?-?) was a high-ranking Suí Dynasty official.

${ }^{99}$ Yáng Liáng 楊諒 (575-605) was the fifth son of the Emperor Yáng Jiān 楊堅 of the Suí Dynasty.
} 
An even more complex example of 'character analysis' occurs in Kumārajīva's biography. At the moment when the Emperor Lü Zuăn 呂纂 (?-401) of the Liáng 涼 Dynasty is about to beat Kumārajīva in a board game (bóyi 博亦), he jokingly exclaims: 斫胡奴頭 ('Cutting off the head of the barbarian slave!') — an allusion to the fact that Kumārajīva hails from Central Asia and as such is considered a 'barbarian'. However, Kumārajīva is seemingly not in a joking mood and reinterprets this phrase as a prediction of the emperor's fate:

One cannot cut off the head of the barbarian slave, but the barbarian slave (胡奴) will cut off the head of a person [i.e. Lü Zuăn].

不能斫胡奴頭, 胡奴將斫人頭。

$$
\text { (GSZ, p332a12-13) }
$$

No one understood this statement at the time, but Lü Zuăn was eventually beheaded by Lü Zhào 呂超, who had launched a revolt against the emperor. The style name of Lü Zhào was Húnù 胡奴' (lit. 'barbarian slave').

\subsection{Unorthodox Prognostication Methods}

In addition to the mainstream prognostication techniques outlined above, the GSZ and XGSZ very occasionally mention highly specialised methods. For example, we learn that Kumārajīva used an unusual technique to determine whether a patient would recover from an illness:

With a multi-coloured silken thread, he would make a rope, join [the two ends] together, and ignite it until it had burned to ashes. Then he would throw it into the water [and observe whether] the ashes appeared on [the surface]; if it still had the shape of a rope, then the sickness could not be cured.

以五色絲作繩，結之燒為灰末，投水中，灰若出水，還成繩者， 病不可愈。

(GSZ, p957c27-28)

Other unusual methods in the historical records include Fótúchéng 佛圖澄 forecasting the auspiciousness of events by listening to the pealing of bells (GSZ, p383b2324) and Băoyì making predictions after turning one hundred shells (GSZ, p345a17). In the entry for the Indian translator Dámójíduō 達摩笈多 (Dharmagupta; ?-619), we learn that a monk from Guăngzhōu consulted a scripture with the title Zhànchá shàn'è yè bào jīng 占察善惡業報經 $\left(\mathrm{T} 17\right.$, no839) ${ }^{100}$ and predicted events by tossing two small leather plaques embossed with the characters shàn 善 ('good > auspicious')

${ }^{100}$ This scripture is traditionally attributed to the Indian monk Pútídēng 菩提燈 (*Bodhidīpa), who was active in China from the end of the 6th to the beginning of the 7th century. However, the text was probably composed in China. 
and $\grave{e}$ 惡 ('bad > inauspicious'). ${ }^{101}$ However, this method was considered heterodox and was prohibited by the government (XGSZ, p435c27-436a1).

Finally, a few monks are depicted as behaving in peculiar or even foolish ways. For example, Făxíng 法行 shoots bamboo arrows at the walls of Dāngyáng 當陽 after predicting that bandits will attack the city. However, the citizens misunderstand his hidden message and are consequently massacred by the intruders (XGSZ, p658b1-12).

\section{Conclusions}

The GSZ and XGSZ are important sources for analysing the significance of prognostication/foreknowledge in Buddhist history texts, and the way in which these abilities were integrated into the biographies of eminent Chinese medieval monks. This paper has also compared aspects of mantic practices recorded in the Chinese Buddhist history texts with the Chinese Buddhist translated literature and the 'Indian' view on prognostication they reflect. Furthermore, it has investigated examples of indigenous Chinese prognostication techniques in the GSZ and XGSZ, and highlighted some differences between the two texts.

Foremost among the various prognostication topics in the Buddhist history texts are the most significant life events of monks, including their gestation, birth, youth and education, and death. Interestingly, there are significant differences between the GSZ and the XGSZ with regard to recording events before, during, and after a monastic's birth. Whereas the former text contains only three narratives on birth events, its sequel features no fewer than twenty-nine. This probably reflects contrasting degrees of interest in the subject in the eras when the two texts were written. Indeed, identical tendencies are evident in contemporaneous secular history texts. For example, little attention is paid to the births of important people in Sòng shu 宋書 or the Nán-Qi sh $\bar{u}$ 南齊書 ${ }^{102}$ (composed around the same time as the GSZ), whereas the Liáng shū 梁書, Chén shū 陳書, and Nán shì 南史 ${ }^{103}$ (all of which, like the XGSZ, were written during the Táng period) include frequent references to such events.

In contrast to birth events, the subject of death (and rebirth destinations) plays a significant role in both of the Buddhist history texts. Overall, 122 prognostication narratives relate to the end of a monk's life. This is hardly surprising, since the moment when an eminent monk dies is viewed as the culmination of his earthly efforts and a direct outcome of his spiritual practice. These narratives may be divided into two main types: the monk's own foreknowledge of his impending death; and accounts of unusual events preceding or coinciding with his passing. The former passages

${ }^{101}$ See Zhuāng 1999: 39. For an English translation of the entire passage, see $\mathrm{Ng}$ 2007: 88.

102 Edited during the Liáng Dynasty.

${ }^{103}$ The Nán shì records special events accompanying the birth of almost every emperor. For example, the text reports unusual lights filling the room and 'sweet dew' (gānlù 甘露) descending when Liú Yù (r. 420-422) of the Sòng and Liú Jùn 劉駿 were born, and similarly unusual natural phenomena coinciding with the birth of the Emperor Tàizǔ 太祖 of the Qí 齊 (see Nán shŭ: 1, 55, $88,97)$. 
were probably included for didactic reasons: such accounts 'proved' that the monk in question had attained a high degree of spiritual insight, knowledge of the past and future, and other special powers as a result of his practice.

The number of narratives relating to strange phenomena either presaging or coinciding with a monk's demise increased significantly from the GSZ (sixteen accounts) to the XGSZ (sixty-nine accounts). Here, once again, the increased emphasis in the later text may reflect the interests of the target audience. The monks' spiritual accomplishments are presented as so significant that the environment (including nature) participates in their 'resonance' (gănyìng 感應). ${ }^{104}$ This notion is traditionally Chinese, but it also echoes nature's (specifically plants', animals', and spirits') interactions with the Bodhisattva (i.e. Buddha in his former lives) in the jātaka and avadāna narratives. Accounts of these events in the history texts also had the important function of emphasising that Buddhist monastics possessed greater spiritual power than their Confucian or Daoist counterparts. This sectarian/propagandist feature is especially prominent in Dàoxuān's work, which was written at a time when Buddho-Daoist competition (see Campany 2012: 273-364) was reaching new heights and Buddhists were facing frequent attacks from Confucian scholars. The compiler's clear intention was to protect the Dharma by focusing on the exemplary features and special powers of Buddhist monastics ( hù fã 護法).

Whereas both texts contain frequent references to eminent monks' foreknowledge and 'signs' relating to important events in their lives, there are far fewer accounts of monastics using specific prognostication techniques: only fourteen in the GSZ, and only thirteen in the XGSZ. In the earlier text, seven of the fourteen prognosticating monks fall within the 'translators' category. This may be explained by the fact that the GSZ includes biographies of relatively early translators, many of whom originated from outside China (primarily Central Asia). In the early period of Chinese Buddhism, before the doctrinal framework, monastic regulations, and institutions had been firmly established, the local audience might have been most interested in the supernatural aspects of the 'new cult', including special techniques (shì 術) of predicting the future. Hence, the compiler of the GSZ probably drew on earlier legends and records concerning the early translators. ${ }^{105}$

Although Dàoxuān was a Vinaya monk and the foremost authority on the Sifên lì 四分律, ${ }^{106}$ there is no explicit or even implicit criticism of monastics' use of supernatural powers and prognostication techniques in the XGSZ. ${ }^{107}$ This suggests that possessing and practising special powers had become an inherent feature of the image of

\footnotetext{
${ }^{104}$ One example is trees turning white when Sēngchè 僧徹 was on the verge of death (XGSZ, p595c13).

${ }^{105}$ Kieschnick 1997: 84-87 discusses the tendency of these texts to ascribe thaumaturgical powers to foreign monks.

${ }^{106}$ The Vinaya literature frequently criticizes monks' use of special powers.

${ }^{107}$ Dàoxuān's fascination with other supernatural powers, in addition to prognostication/divination, is evident in his accounts of famous monks taming wild beasts, causing dry springs to gush again, communicating with and controlling spirits, reading minds, and causing inexplicable phenomena to occur - to name just a few.
} 
the ideal monk by the early Táng. At most, and only occasionally, we may detect certain ambivalence on the part of Dàoxuān in his treatment of the topic.

Another important aspect of the Buddhist histories is their inclusion of specifically Chinese methods of prognostication, even though these are usually mentioned only in generic terms. The focus on aspects of the Chinese language and script is particularly noteworthy. Such predictions were not straightforward, but rather 'hidden' in riddle-like phrases or convoluted arrangements of Chinese characters. These 'games' that played with the sounds, meanings, and orthographical forms of Chinese words may be traced all the way back to the early Hàn Dynasty - or even earlierand thereafter they appeared in numerous variations and forms in both secular and religious texts. In later works, the phenomenon is sometimes termed chèn 讖, which the Sikù quánshū zǒngmù 四庫全書總目 defines as "composing "hidden/secret words" in a wily way in order to predict the auspicious or inauspicious' (識者, 詭為隱語, 預決吉凶; Yingyìn Wényuān gé Sikù quánshū, cè 1: 158). In China, these yìnyǔ probably became popular because they enabled secular writers to express politically sensitive messages discreetly. ${ }^{108}$ Buddhist writers may well have appreciated the benefits of adopting a similar approach.

Somewhat paradoxically, although the GSZ and XGSZ criticise 'Brahmins' for practising aberrant forms of prognostication, they suggest that similar special powers (sānming liùtōng 三明六通) are natural by-products of rigorous self-cultivation and the attainment of spiritual insight. Hence, the ability to predict the future is 'self-generated' and usually does not have to be mediated by another thaumaturge or a spirit (although, in some biographies, spiritual beings do provide monks with information about future events). Indeed, in contrast to traditional Chinese views on spirits (shén 神) - which cast them transcending the mundane world and being generally superior to human beings ${ }^{109}$ - the Buddhist historical texts downplay their significance and stress the supremacy of human rebirth, even over existence as a deity (tiān 天).

As for the subjects and types of prognostication that feature in the GSZ and XGSZ, the texts present an interesting combination of Indian and Chinese elements. The emphasis on events relating to birth, spiritual attainment, and death was certainly inspired by narratives of Śākyamuni Buddha himself. However, as we have seen, supernatural occurrences at moments of birth and death occasionally feature in nonBuddhist sources, too. Whereas the revelation of future events in dreams is a recurring

${ }^{108}$ An example is the phrase '印金修德為天子' in the Hòu Hànshū (p22). In this phrase, măo jīn 印金 makes no sense at the level of a surface reading. However, these two characters are structural parts of the graph liu 劉. As such, the prediction that Liú Xiù 劉秀 will become emperor is expressed indirectly.

${ }^{109} \mathrm{Cf}$. the famous passage in the Mòzi (祭祀上帝, 鬼、神, 而求祈福於天; p294). Secular historical records frequently include accounts of prayers being said to spirits/supernatural beings to secure their assistance in averting disaster and securing prosperity. Such accounts are very rare in the Buddhist historical texts. By contrast, there is an emphasis on eminent monks' ability to mediate between the human world and the spirits because of their superior knowledge, and they are even sometimes credited with warding off malignant demons. For a number of interesting examples, see the long biography of Sēngchóu 僧稠 in XGSZ, p553b25-555b25.

Acta Orient. Hung. 73, 2020 
topic in the Buddhist history texts, ${ }^{110}$ this type of foreknowledge is clearly a crosscultural phenomenon. Naturally, the agents and objects in the dreams described in the GSZ and XGSZ often have specific Buddhist references. Other techniques that feature in the two texts were widely practised in both Indian/Central Asian and Chinese contexts, such as physiognomising (with some differences concerning the objects to be investigated) and prognostications based on astronomical and atmospheric phenomena. Once again, details of these practices (e.g. the constellations involved or the geographical areas affected) have more specific cultural references.

A few of the techniques described in the GSZ and XGSZ - such as Kumārajīva's predictions of recovery from disease based on his observation of burned silk threads, Ān Shìgāo's interpretations of birds' and animals' calls, and prognostication based on counting shells - are unknown in pre-Buddhist Chinese sources. Hence, it might be surmised that they originated in Central Asia. ${ }^{111}$ Traditional Chinese techniques are easier to identify due to their clear cultural references, including prognostications based on the Zhouyi, the cosmic board, the apocryphal texts, and the Chinese language and script.

More generally, this analysis has highlighted the great significance accorded to prognostication - as well as an array of other supernatural powers - in monastic biographies. Clearly, by the time that the GSZ and XGSZ were composed, these qualities were viewed as essential characteristics of eminent monks.

\section{References}

\section{Primary Sources, Collections, and Dictionaries}

CBETA: Chinese Electronic Tripitaka, distributed by the Chinese Buddhist Electronic Text Association (http://www.cbeta.org).

DDB: Digital Dictionary of Buddhism. http://www.buddhism-dict.net/ddb/.

GSZ: Gāosēng zhuàn 高僧傳, CBETA: T50, no2059.

Hànshū 漢書; by Bān Gù 班固 (32-92). Běijīnng: Zhōnghuá Shūjú, 1962.

Hòu Hànshū 後漢書; by Fàn Yè 范曄 (during the Sòng 宋 of the Southern Dynasties). Běijīng: Zhōnghuá Shūjú, 1965.

Jiù Táng shū 舊唐書; by LIÚ Xù 劉㽛 (887-946) et al. Běijīng: Zhōnghuá Shūjú, 1975.

Lèi biān Cháng'ān zhì 類編長安志; by Luó Tiānxiāng 駱天驤 (Yuán Dynasty). Běijīng: Zhōnghuá Shūjú, 1990.

Lùnhéng jiàoshi 論衡校釋; by Huáng Hū 黄晖. Běijīng: Zhōnghuá Shūjú, 1990.

Ming kānběn Yímén guăngdú 明刊本夷門廣牘; ed. by Wáng Yúnwǔ 王雲五. Táiběi: Shàngwù Yìnshūguăn, 1969.

${ }^{110}$ Of course, revelations in dreams also comprise an important topic in early non-Buddhist Chinese literature; see e.g. Chén 1995. On the relationship between dreams, divination, and statecraft, see Brennan 1993.

${ }^{111}$ The case for this conjecture is strongest with respect to the latter technique, as historical records reveal that Central Asian traders used shells as currency up to the Táng Dynasty; see e.g. Jiù Táng shū: 5307. 
Mòzĭ jiàozhù 墨子校注; by Sūn Qīzhì 孫啟治. Běijīng: Zhōnghuá Shūjú, 1993.

Nán shı̌ 南史; by Lǐ Yánshòu 李延壽 (Táng Dynasty). Běijīng: Zhōnghuá Shūjú, 1975.

Sāndòng qúnxiān lù 三洞群仙錄. In: Dàozàng 道藏, Vol. 32. Shànghăi: Wénwù Chūbănshè, Shànghăi Shūdiàn / Tiānjīn Gŭjí Chūbănshè, 1988.

Shüji 史記; by Sīmă Qiān 司馬遷. Běijīng: Zhōnghuá Shūjú, 1959.

Shisān jīng zhùshū 十三經注疏; ed. by Ruăn Yuán 阮元 (1764-1849). Běijīng: Zhōnghuá Shūjú, 1980.

Tiānyū gé cáng Míng-dài fāngzhì xuănkān xùbiān 天一閣藏明代方志選刊續編. Shànghăi: Shànghăi Shūdiàn Chūbănshè, 1990.

Wèi shū 魏書; by Wèi Shōu 魏收. Běijīng: Zhōnghuá Shūjú, 1974.

XGSZ: Xù gāosēng zhuàn 續高僧傳, CBETA: T50, no2060.

Xīn Táng shū 新唐書; by Ōu Yángxiū 歐陽修. Běijīng: Zhōnghuá Shūjú, 1975.

Xù xiū Sikù quánshū 續修四庫全書; ed. by Xù xiū Sìkù quánshū biānzhuàn wěiyuánhuì 《續修四 庫全書》編撰委員會. Shànghăi: Shànghăi Gŭjí Chūbănshè, 2002.

Xúnzǐ jíjiě 荀子集解; annotated by Wáng Xiānqiān 王先謙 (Qīng Dynasty); ed. by Chén Xiàohuán 沈啸寰 and Wáng Xīngxián王星贤. Běijīng: Zhōnghuá Shūjú, 1988.

Y̌ngyìn Wényuān gé Sikù quánshū 影印文淵閣四庫全書. Táiběi: Shàngwù Yìnshūguăn, 1983.

Zhōuyì jíjiě 周易集解; by Lỉ Dĭngzuò 李鼎祚 (Táng Dynasty); ed. by Wáng Fēngxiān 王丰先. Běijīng: Zhōnghuá Shūjú, 2016.

Zhuāngzĭ jíshì 莊子集釋; ed. by Guō Qìngfān 郭慶藩 and WÁNG Xiàoyú 王孝魚. Běijīnng: Zhōnghuá Shūjú, 1961.

\section{Secondary Sources}

ASSANDRI, Friederike 2009. 'Inter-religious Debate at the Court of the Early Tang: An Introduction to Daoxuan's Ji gujin Fo Dao lunheng.' In: Friederike ASSANDRI and Dora MARTINS (eds.) From Early Tang Court Debates to China's Peaceful Rise. Amsterdam: Amsterdam University Press, $15-32$.

ATSUSHI Ibuki 伊吹敦 1990. 'Zokukōsōden no zōkō ni kan-suru kenkyū 続高僧伝』の増広に関 する研究 [A study on the expansion of the Xù gāosēng zhuàn].’ Tōyō no shisō to shükyō 東洋の思想と宗教 7: 58-74.

ATsUSHI Ibuki 伊吹敦 1992. 'Guānyú Xù gāosēng zhuàn zhī zēngbǔ 矢于 《续高僧傅》之增补.' Dìguān 谛观 69: 197-221. (Translation of Atsushi 1990 into Chinese by Shì Zhàohuì 释昭 慧.)

BenN, James 2007. Burning for the Buddha: Self-immolation in Chinese Buddhism. [Kuroda Institute Studies in East Asian Buddhism 19.] Honolulu: University of Hawai i Press.

BREnNAN, John 1993. 'Dreams, Divination and Statecraft: The Politics of Dreams in Early Chinese History and Literature.' In: Carol Schreier RuPPRECHT (ed.) The Dream and the Text: Essays on Literature and Language. Albany, NY: Suny Press, 73-102.

CAMPANY, Robert F. 1990. 'Return-from-Death Narratives in Early Medieval China.' Journal of Chinese Religions 18/1: 91-125.

Campany, Robert F. 1996. Strange Writing: Anomaly Accounts in Early Medieval China. New York: State University of New York Press.

CAMPanY, Robert F. 2012. Signs from the Unseen Realm: Buddhist Miracle Tales from Early Modern China. Honolulu: University of Hawai'i Press.

ChaVANNES, Edouard 1962. Cinq cents contes et apologues extraits du tripitaka chinois et traduits en français. Paris: Adrien-Maisonneuve. 
Chemla, Karine, Donald Harper and Marc Kalinowski (eds.) 1999. Divination et rationalité en Chine ancienne. [Extrême-Orient, Extrême-Occident 21.] Paris: Presses Universitaires de Vincennes.

Chen, Jinhua 2016. 'Manuscripts, Printed Canons, and Extra-canonical Sources: A Case Study Based on a Biography from the $X u$ Gaoseng Zhuan (Further biography of eminent monks) by Daoxuan 道宣 (596-667).' Studies in Chinese Religions 2/2: 137-156.

CHÉN Měiyīng 陳美英 et al. 1995. Zhōnghuá zhàn mèng shù 中華占夢術 [The art of Chinese dream divination]. Taipei: Wénjīn.

CHÉN Yuán 陳垣 2005. Zhōngguó fójiào shŭji gàilùn 中國佛教史籍概論 [An outline of Chinese Buddhist historical records]. Shànghăi: Shànghăi Shūdiàn Chūbănshè.

Cullen, Christopher 2011. 'Understanding the Planets in Ancient China: Prediction and Divination in the Wu xing zhan.' Early Science and Medicine 16/3: 218-251.

Cullen, Christopher 2017. Heavenly Numbers: Astronomy and Authority in Early Imperial China. Oxford: Oxford University Press.

DAvIs, Scott 2012. The Classic of Changes in Cultural Context: A Textual Archaeology of the Yi Jing. Amherst, NY: Cambria Press.

Despeux, Catherine 2003. 'Physiognomie.' In: Marc Kalinowski (ed.) Divination et Société dans la Chine Médiévale: Étude des Manuscrits de Dunhuang de la Bibliothèque Nationale de France et de la British Library. Paris: Bibliothèque Nationale de France, 513-555.

Guggenmos, Esther-Maria 2018. 'A List of Magic and Mantic Practices in the Buddhist Canon.' In: LACKNER 2018: 151-195.

HARPER, Donald 1979. 'The Han Cosmic Board (shih 式).' Early China 4: 1-10.

HIRAKAWA Akira 平川彰 1997. Bukkyō kan-bon dai jiten 佛教漢梵大辭典 [Buddhist ChineseSanskrit dictionary]. Tōkyō: Reiyūkai.

IRIYA Yoshitaka 入矢義高 and KoGA Hidehiko 古賀英彦 1991. Zengo jiten 禅語辞典 [A dictionary of Zen vocabulary]. Kyōto: Shibunkaku.

Jensen, Christopher 2018. Dreaming Betwixt and Between: Oneiric Narratives in Huijiao and Daoxuan's Biographies of Eminent Monks. (Ph.D. dissertation, McMaster University.)

Kalinowski, Marc (ed.) 2003. Divination et Société dans la Chine Médiévale: Étude des Manuscrits de Dunhuang de la Bibliothèque Nationale de France et de la British Library. Paris: Bibliothèque Nationale de France.

KARCHER, Stephan 2002. I Ching: The Classic Chinese Oracle of Change. London: Vega.

KAWAI Kōzō 川合康三 and KozEN Hiroshi 興膳宏 1995. Zui sho keisekishi shōkō 隋書經籍志詳 敃 [A thorough investigation of texts and records referred to in the Suíshū]. Tōkyō: Kyuko shoin.

KIESCHNICK, John 1997. The Eminent Monk: Buddhist Ideals in Medieval Chinese Hagiography. Honolulu: University of Hawai i Press.

Kотук, Jeffrey. 2017a. Buddhist Astrology and Astral Magic in the Tang Dynasty. (Ph.D. dissertation, Leiden University.)

Kотук, Jeffrey 2017b. 'Can Monks Practice Astrology? Astrology and the Vinaya in China.' In: Susan ANDREW, Jinhua CHEN and Cuilan LiU (eds.) Rules of Engagement: Medieval Traditions of Buddhist Monastic Regulations. Hamburg: Hamburg University Press, 503-517.

Kотук, Jeffrey 2018. 'The Sinicization of Indo-Iranian Astrology in Medieval China'. Sino-Platonic Papers 282: 1-95.

Kroll, Paul W. 2018. 'The Representation of Mantic Arts in the High Culture of Medieval China.' In: LACKNER 2018: 99-125.

LACKNER, Michael (ed.) 2018. Coping with the Future: Theories and Practices of Divination in East Asia. Leiden and Boston, MA: Brill. 
LAI, Whalen 2003. 'The Century of the Holy Man in Chinese History (316-439): The Death of Hsuan-Kao.' Pacific World: Journal of the Institute of Buddhist Studies (Third Series) 5: $143-161$.

Li, Jung-hsi (= Li Rongxi) and Albert A. DALIA (trans.) 2006. Lives of Great Monks and Nuns [BDK English Tripitaka Translation Series, Book 76.] Berkeley, CA: Numata Center for Buddhist Translation and Research.

Lǐ Líng 李零 1993. Zōngguó fāngshù kăo 中國方術考 [A study on Chinese divination]. Běijīng: Rénmín Zhōngguó Chūbănshè.

LI, Wai-yee 2007. The Readability of the Past in Early Chinese Historiography. [Harvard East Asian Monographs 253.] Cambridge, MA: Harvard University Asia Center.

LiPPIEllo, Tiziana 2001. Auspicious Omens and Miracles in Ancient China: Han, Three Kingdoms and Six Dynasties. [Monumenta Serica Monograph Series 39.] Sankt Augustin: Institut Monumenta Serica; Nettetal: Styler Verlag.

MAK, Bill M. 2014. 'Yusi Jing: A Treatise of 'Western' Astral Science in Chinese and its Versified Version Xitian yusi jin.' SCIAMVS 15: 105-169.

MAK, Bill M. 2015. 'The Transmission of Buddhist Astral Science from India to East Asia: The Central Asian Connection.' Historia Scientiarum 24/2: 59-75.

MeISIG, Konrad 1987. Das 'Śrāmanyaphala-Sütra': Synoptische Übersetzung und Glossar der chinesischen Fassungen verglichen mit dem Sanskrit und Pāli. Wiesbaden: Harrassowitz.

NAKAMURA Hajime 中村元 1975. Bukkyōgo daijiten 仏教語大辭典 [Encyclopedic dictionary of Buddhist terms]. Tōkyō: Tōkyō Shoseki.

NATTIER, Jan 2008. A Guide to the Earliest Chinese Buddhist Translations: Texts from the Eastern Han 東漢 and Three Kingdoms 三國 Periods. Tokyo: International Research Institute for Advanced Buddhology, Soka University.

NG, Zhiru 2007. The Making of a Savior Bodhisattva: Dizang in Medieval China. [Kuroda Institute Studies in East Asian Buddhism 21.] Honolulu: University of Hawai'i Press.

Nielsen, Bent 2018. 'Hexagrams and Prognostication in the Weishu Literature: The Thirty-twoyear Cycle of the Qian zuo du.' In: LACKNER 2018: 47-98.

Noegel, Scott 2007. Nocturnal Ciphers: The Allusive Language of Dreams in the Ancient Near East. New Haven, CT: American Oriental Society.

Ohnuma, Reiko 2017. Unfortunate Destiny: Animals in the Indian Buddhist Imagination. New York: Oxford University Press.

Pankenier, David W. 2013. Astrology and Cosmology in Early China: Conforming Earth to Heaven. Cambridge: Cambridge University Press.

RAPHAls, Lisa 2008-2009. 'Divination in the 'Han Shu' Bibliographic Treatise.' Early China 32: $45-101$.

Raphals, Lisa 2013. Divination and Prediction in Early China and Ancient Greece. Cambridge: Cambridge University Press.

SHARF, Robert 2002. Coming to Terms with Chinese Buddhism. Honolulu: University of Hawai' $\mathrm{i}$ Press.

SHINOHARA, Koichi 1992. 'Guanding's Biography of Zhiyi, the Fourth Patriarch of the Tiantai Tradition.' In: Phyllis Granoff and Koichi ShinOHARa (eds.) Speaking of Monks: Religious Biography in India and China. Oakville, ON: Mosaic Press, 97-218.

SHINOHARA, Koichi 1994. 'Biographies of Eminent Monks in a Comparative Perspective: The Function of the Holy in Medieval Chinese Buddhism.' Zhōnghuá fóxué xuébào 中華佛學學報 7: 479-498.

SHì Zhàohuì 釋昭慧 (tr.) 1992. 'Guānyú Xù gāosēng zhuàn zhī zēngbǔ 關於《續高僧傳》之增 補.' Diguān 諦觀 69: 197-221. [This is a translation of Atsushi 1990 into Chinese.] 
SteAvu, Dominic 2018. 'The Allegorical Cosmos: The Shi 式 Board Medieval Taoist and Buddhist Sources.' In: LACKNER 2018: 196-232.

Stevens, Anthony 1997. Private Myths: Dreams and Dreaming. Cambridge, MA: Harvard University Press.

STRASSBERG, Richard E. 2008. Wandering Spirits: Chen Shiyuan's Encyclopedia of Dreams. Berkeley, Los Angeles and London: University of California Press.

Strickmann, Michel 2005. Chinese Poetry and Prophecy: The Written Oracle in East Asia. Ed. by Bernard FAURE. Stanford, CA: Stanford University Press.

UTSUO Shōshin 撫尾正信 1954. 'Makamaya kyō kanyaku ni kansuru gigi 摩訶摩耶経漢訳に関す る疑義 [Doubtful aspects concerning the Chinese translation of the Mahāmāya sūtra].' Saga Ryūkoku gakkai kiyō 佐賀龍谷学会紀要 2: 1-28.

Wright, Arthur F. 1954. 'Biography and Hagiography: Hui-Chiao's Lives of Eminent Monks.' In: Silver Jubilee Volume of the Zinbun kagaku kenkyūsho. Kyoto: Kyoto University, 383-432.

YANG, Lu 2004. 'Narrative and Historicity in the Buddhist Biographies of Early Medieval China: The Case of Kumārajīva.' Asia Major 17/2: 1-43.

ZHUĀNG Míngxīng 莊明興. 1999. Zhōngguó zhōnggŭ de Dizàng xìnyăng 中國中古的地藏信仰 [Faith in Kșitigarbha during the Chinese Middle Ages]. Taipei: National Taiwan University Press.

\section{Acknowledgements}

We want to express our sincere gratitude to the editors of Acta Orientalia Academiae Scientiarum Hungaricae for their help throughout the publication process of this paper, and the two anonymous reviewers for their many useful comments and additional references. We also want to thank Philip Parr for proofreading the paper.

The work on this paper was generously supported by grants from the Chinese Scholarship Council (CSC) and the University of British Columbia project From the Ground Up: Buddhism and East Asian Religions, sponsored by the Social Sciences and Humanities Research Council (SSHRC) of Canada.

Open Access. This is an open-access article distributed under the terms of the Creative Commons Attribution-NonCommercial 4.0 International License (https://creativecommons.org/licenses/by-nc/4.0/), which permits unrestricted use, distribution, and reproduction in any medium for non-commercial purposes, provided the original author and source are credited, a link to the CC License is provided, and changes - if any - are indicated. 
